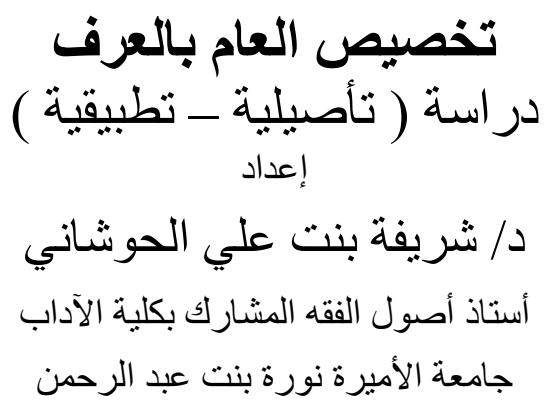

ملخص البحث :

الحمد لله رب العالمين ، و الصـلاة و السـلام على أثشرف الأنبياء و المرسلين ، نبينـا

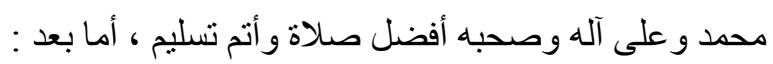

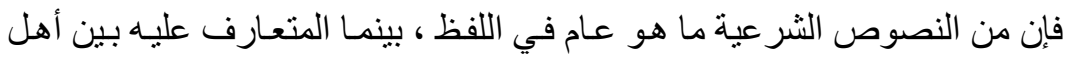

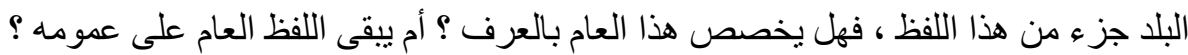

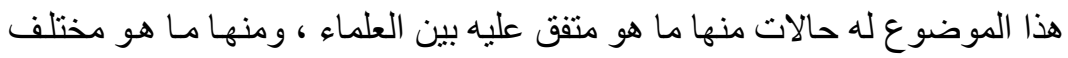

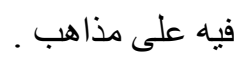

فالمتفق عليها : أن تخصيص النص العام بـالعرف في زمن النبي صلى الله عليه

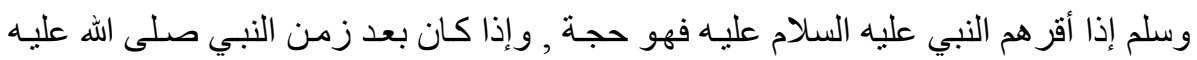
وسلم وفي زمن الصحابة وخصص العام بالعرف ولم ينكر أحد منهم فهو حجة أيضاً.

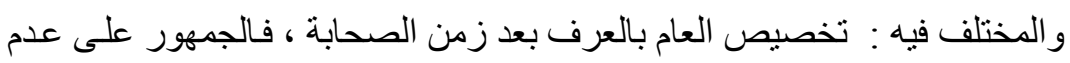
جواز تخصيص النص الثرعي العام بالعرف .

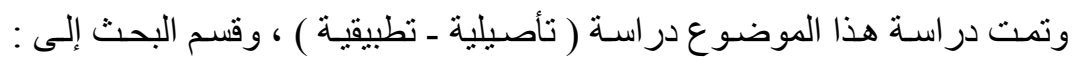

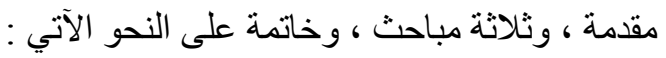

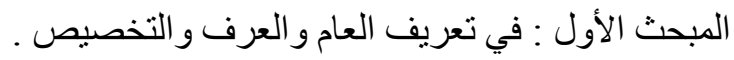

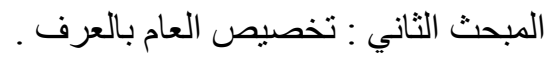

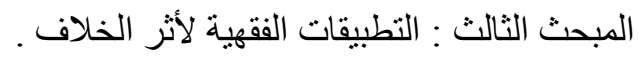
الخاتمة . هذا وصلى الله على نبينا محمد و على آله وصحبه وسلم . بسم الله الرحمن الرحيم 


\section{تخصيص العام بالعرف}

الحمد الله رب العالمين و الصداة و السلام على أشـرف الأنبيـاء و المرسلين ، نبينـا محمد

$$
\text { و على آله وصحبه وسلم ، أما بعد : }
$$

فإن علم أصسول الفقه مـن أجل العلوم الثـرعية وأشـرفها ، ذلك لأن الحيـاة البشرية بحاجة إلى ضو ابط و أحكام شر عية تسبر عليها في جميع مجالاتها ، لتستقيم أمور هـاوتنتظم أحو الها . أحها

وفي الثريعة أصول وثوابت لا نتغير بتغير الزمان والمكان ، وفروع متغيرة في كل زمان ومكان ، فتبنى هذه الفروع على تللك الأصول ليبين حكم الله فيها ، ومن هذه المتغير ات أعر اف الناس القولية و العملية .

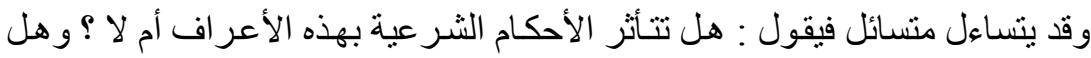

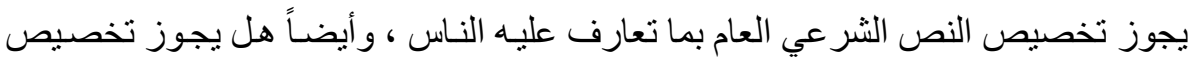

ألفاظ المكلفين العامة بما تعارفو ا عليه أم لا ؟؟ وهذه التساؤلات محل خلاف بين العلماء !

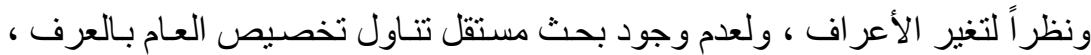
حيث إن الموجود متفرق بين الموضو عات في كتب أصول الفقه ، أو أثـير لـه ضـن بحوث خاصة عن العرف ، لذا آثرت در اسة هذه الجزئية در اسـة تأصيلية تطبيقية مـا أمكن ، وكـان المنهج المتبع في هذه الدراسـة منهج الوصف و الاسـتقر اء و التحليل والإستنتاج ، مـن خـلال الخطو ات العلمية و التي منها :

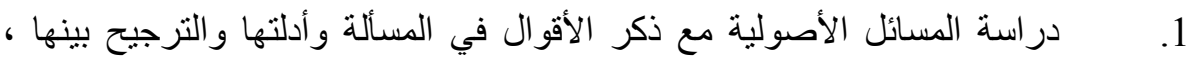
و إحالتها إلى المصادر الأصولية ، مع محاولة أن نشمل هذه المصادر جميع المذاهب الأصولية

2. دراسة موجزة لأقو ال الفقهاء في الفروع الفقهية وبيان وجه البناء ، مع الإحالة إلى

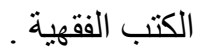

3. تعريف المصطلحات الأصولية لغة واصطلاحاً ، مع ذكر تعريفات العلماء للمصطلح و الترجيح بينها ، و الإشارة إلى مصادر ها . 4. ترقيم الآيات مع ذكر اسم السورة . 5. تخريج الأحاديث من الكتب الستة ومن مظان الحديث مع ذكر المصادر . 6.

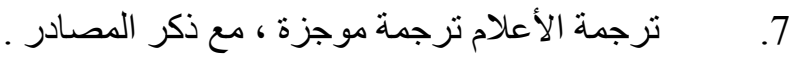
وقد تم تقسيم البحث إلى : مقدمة ، وثناثة مباحث ، وخاتمة ، على النحو الآتي : المقدمة .

المبحث الأول : في تعريف العام ، و العرف ، و التخصيص ، ويشمل ثثلثنة مطالب : المطلب الأول : في تعريف العام و ألفاظه . 


$$
\text { د/ شريفة بنت علي الحوشاني }
$$

المطلب الثاني : في تعريف العرف و الفرق بينه وبين العادة .

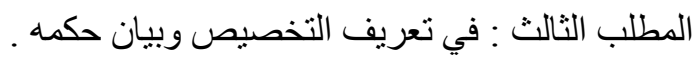

المبحث الثاني : في تخصيص العام بالعرف .

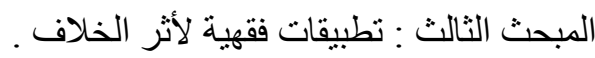

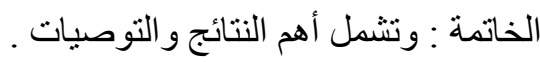

هذا وأسأل الله التوفيق و السداد ، وصلى الله على نبينا محمد و على آله وصحبه وسلم . 


$$
\text { تخصيص العام بالعرف }
$$

في تعريف العام ، والعرف ، والتخصيص ، ويشمل ثلاثة مطالب :

المطلب الأول : في تعريف العام و ألفاظه .

المطلب الثاني : في تعريف العرف والفرق بينه وبين العادة .

المطلب الثالث : في تعريف التخصيص وبيان حكمه . 


\section{د/ شريفة بنت علي الحوشاني

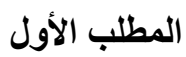 \\ تعريف العام وألفاظه}

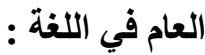

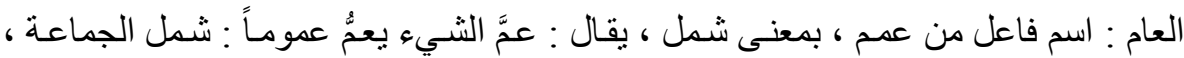

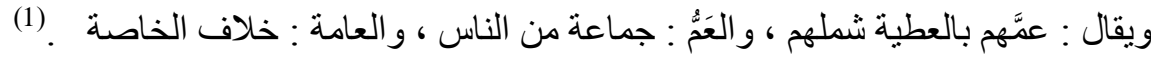

العام في الاصطلاح :

عرفه العلماء بعدة تعريفات : فعند أبي زيد الدبوسي(2) (ت430هـ) هو : " ما ينتظم جمعاً من

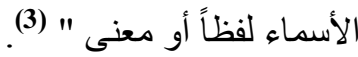
و عند أبي الحسين البصري(4) (ت 436هـ) : " العام كلام مستغرق لجميع ما يصلح له

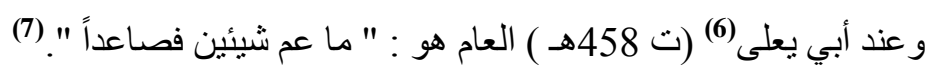

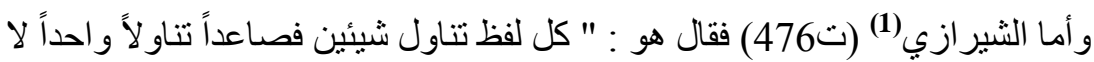

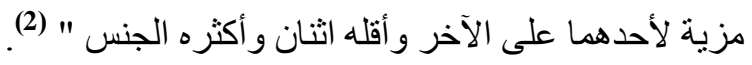

$$
\text { انظر : مادة ( عمم ) في الصحاح (1991/5) ، لسان العرب (423/12) . }
$$

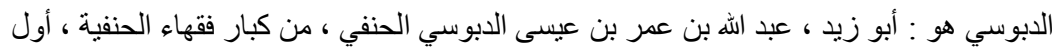

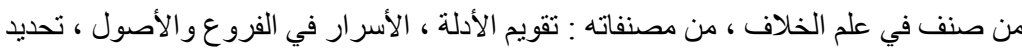

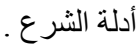
انظر : وفيات الأعيان (253/1) ، سير أعلام النبلاء (337/13) .

$$
\text { تقويم الأدلة (94) . وفئن الاعيان }
$$

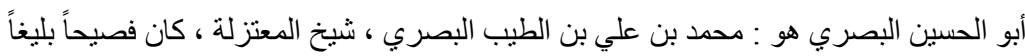

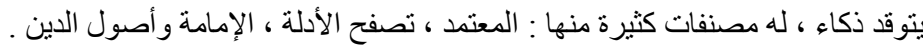

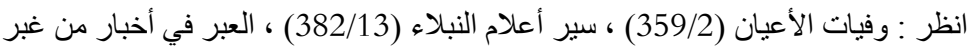

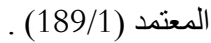

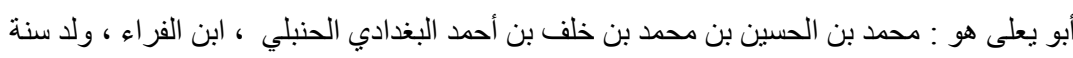

(380هـ) ، شيخ الحنابلة في عصره ، أصولي محدث ، من مصنفاته ، أحكام القرآن ، ومسائل

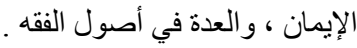
انظر : سير أعلام النبلاء (488/13) ، طبقات الحفاظ (1132/3) .

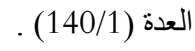


و العام عند الغزالي(3) (ت505هـ) هو : " عبارة عن اللفظ الواحد الدال من جهة واحدة على شيئين فصاعداً "(4). وقال أبو الخطاب الكلوذاني (5) (ت 510هـ) العام هو : " كلام مستغرق لجميع ما يصلح له (6)" و وأما الرازي(7) (ت 606هـ) فقال في تعريفه هو : " اللفظ المستغرق لجميع ما يصلح له بحسب وضع واحد " (8).

و عند الآمدي(9) (ت 631هـ) العام هو : " اللفظ الو احد الدال على مسميين فصاعداً مطلقاً معاً " (10).

الثيرازي هو : إبر اهيم بن علي بن يو سف ، أبو إسحاق ، فقيه أصولي شافعي اشعري ، امتاز

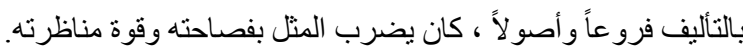
انظر : وفيات الأعيان (22/1) ، سير أعلام النبلاء (7/14) .

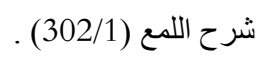

الغز الى هو : محمد بن محمد بن محمد بن أحمد الطوسي الغزالي الثافعي ، أبو حامد ، ولد سنة

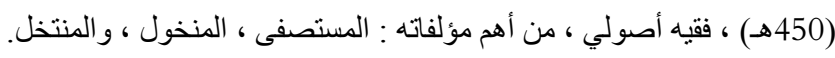

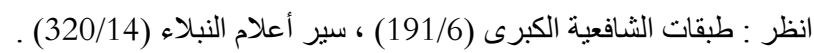
المستصفى (32/2) .

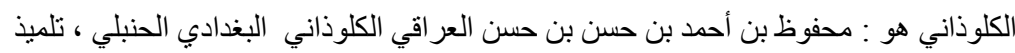

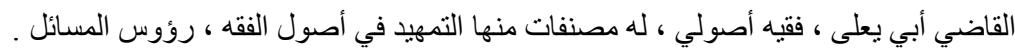

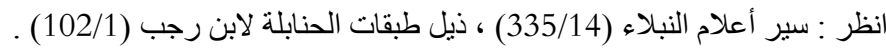

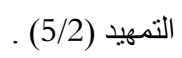

الرازي هو : فخر الدين محمد بن عمر بن الحسين بن الحسن بن علي التيمي البكري الطبرستاني

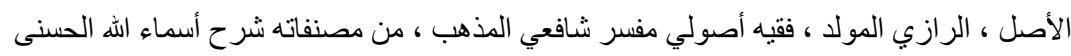

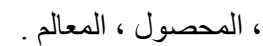
انظر : وفيات الأعيان (349/2) ، سير أعلام النبلاء (54/16) .

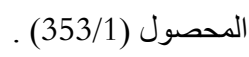

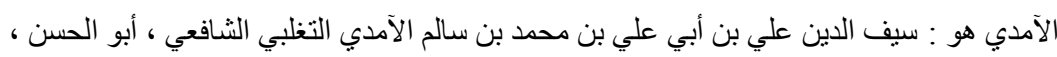

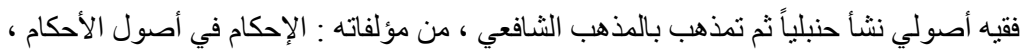

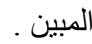
انظر : طبقات الثافعية لابن شهبة (80/2) ، شذرات الذهب (101/5) .

$$
\text { الإحكام في أصول الأحكام (413/1) . }
$$




$$
\text { د/ شريفة بنت علي الحوشاني }
$$

و أما ابن الحاجب(1) (ت 646هـ) فقال العام هو : " ما دل على مسميات باعتبار أمر اشتركت فيه مطلقاً ضربة "(2) أي : دفعة .

و عند القر افي (3)(ت 684هـ) هو :" الموضو ع لمعنى كلي بقيد تتبعه في محاله" . و المر اد بالتتبع في المحال : أي بالحكم كان وجوباً أو تحريماً أو إباحة أو خبراً أو

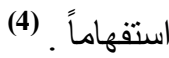

و أما ابن تيمية(5) (ت 728هـ) أخذ تعريف أبي يعلى فقال : " العموم ما عم شيئين

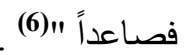
و عند الإسنوي(7) (ت 772هـ) : " العام لفظ بستخرق جميع ما يصلح له بوضع واحد

وابن الهمام(1) (ت 790هـ) قال هو : " ما دل على استغراق أفر اد مفهوم" وهو اختيار

$$
\text { اختبار صاحب كتاب فو اتح الرحموت(2) . }
$$

ابن الحاجب هو : جمال الدين ، أبو عمرو ، عثمان بن عمر بن أبي بكر الكردي المصري ، المالكي

، المقرئ ، النحوي ، الأصولي ، له مصنفات منها : منتهى السول و الأمل ، و الأمالي في النحو . انظر : وفيات الأعيان (314/1) ، العبر للذهبي (253/3) ، الأعلام (374/4) .

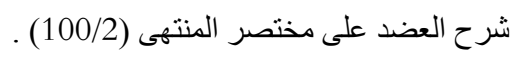

القر افي هو : شهاب الدين أحمد بن إدريس بن عبد الرحمن الصنهاجي القرافي ، أبو العباس ، من

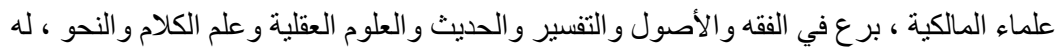

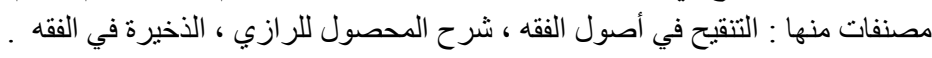
انظر : الديباج المذهب ( 62) ، الأعلام (90/1) .

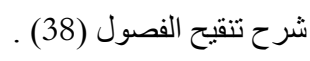

ابن تيمية هو : تقي الدين أحمد بن شهاب الدين عبد الحليم بن مجد الدين عبد السلام الدمشقي الحنبلي

، أبو العباس ، ولد بحران سنة (661هـ) ، شيخ الإسلام ، المحقق ، الحافظ ، المجتهد ، المحدث ، المفسر ، الأصولي ، له مصنفات كثيرة .

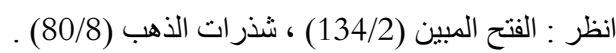

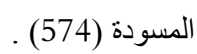

الإسنوي هو : عبد الرحيم بن الحسن بن علي الإسنوي الثافعي ، من علماء الثريعة ، مؤرخ وفقيه

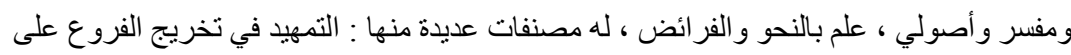
الأصول . أنطر واصول

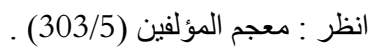

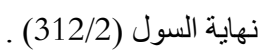


و أما ابن النجار (3) (ت 972هـ) فقال هو : " لفظ دال على جميع أجز اء ماهية مدلوله

و عند محمد أمين(5) (ت 972هـ ) هو : " ما دل على استغراق أفراد مفهوم " (6). وبالنظر إلى ماسبق أجد أن العلماء اختلفوا في حده ، فمنهم من أخذ تعريف من سبقه

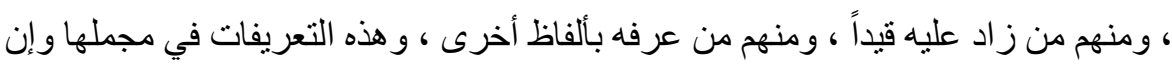
اختلفت في الألفاظ إلا أنها منقاربة في المعنى ، وسبب الاختلاف قي الألفاظ ، يعود إلى ما ورد على هذه التعريفات من نقد واعتر اضات وكل يحاول أن يستدرك ما فات غيره ، ويمكن

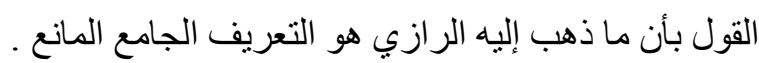

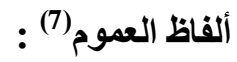
للعموم في اللغة ألفاظ خاصة موضو عة لله تدل على العموم حقيقة وهي : أدوات الاستفهام : من للعاقل ، ما لغير العاقل ، أي للعاقل ولغير العاقل ،

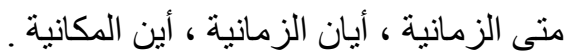
2. أدو ات الثرط : من للعاقل ، ما لغير العاقل ، أي للعاقل ، أين المكانية ، متى الزمانية

ابن الهمام هو : كمال الدين محمد بن عبد الواحد بن عبد الحميد الإسكندري الحنفي ، ولد سنة

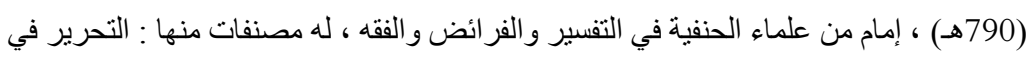

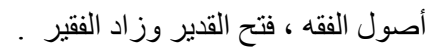
انظر : الجواهر المضية في طبقات الحنفية (86/2) ، الأعلام (134/7) . فو اتح الرحموت (255/1) .

ابن النجار هو : تقي الدين محمد بن شهاب الدين أحمد بن عبد العزيز بن علي الفتوحي الحنبلي ، ولد بمصر سنة (868 هـ) ، أخذ العلم عن علماء مصر ومنهم والده ، كان رجلاً صالحاً تقياً ورعاً عفيفاً ، وقد برع في العلوم الثرعية ، من أبرز مؤلفاته : شرح الكوكب المنير ، منتهى الإر ادات .

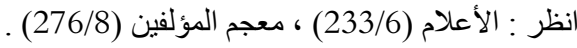

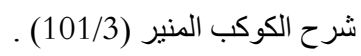

هو : محمد أمين بن محمود البخاري ، المعروف بأمير بادشاه ، فقيه ، حنفي محقق ، من أهل

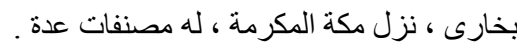

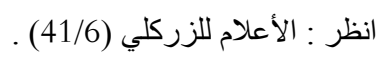

تيسير التحرير (190/1) . تانئ

انظر ألفاظ العموم في : التمهيد للكلوذاني (5/2) ، الإحكام للآمدي (415/1) ، تيسير التحرير

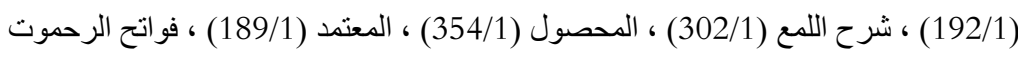

(256/1) ) ، إرشاد الفحول (115) (1) (1) 


$$
\text { د/ شريفة بنت علي الحوشاني }
$$

3. لفظ : " كل "و " جميع " . 4. الجمع المعرف بأل . 5. الجمع المعرف بالإضافة . 6. واو الجماعة . 7. النكرة في سياق النفي . 8. المفرد المحلى بأل . 9. المفرد المعرف بالإضافة . 10. الاسم الموصول : الذي ، التي ، اللتان ، اللذين ، الذين ، اللاتي ، اللائي . 


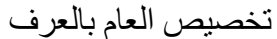 \\ المطلب الثاني \\ تعريف العرف والفرق بينه وبين العادة}

\section{العرف في اللغة :}

العرف : بكسر العين وفتحها وضمها مع سكون الر اء في الجميع يطلق على عدة معان

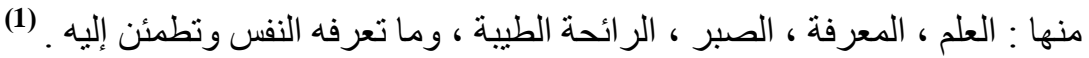

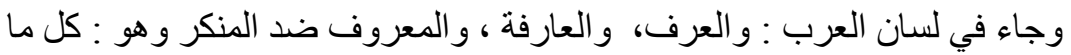

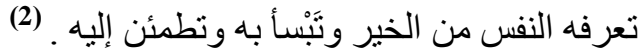

\section{العرف في الاصطلاح :}

ذكر العلماء له تعريفات متقاربة في الألفاظ متفقة في المعنى ، منها :

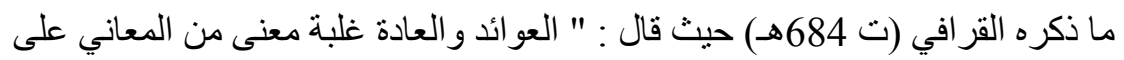

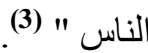

و عند الكمال بن الهمام (ت 790هـ) العرف هو : " الأمر المتكرر من غير علاقة

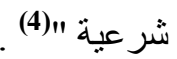

و عند الجرجاني(5) (ت 816هـ) هو : " ما استمر الناس عليه على حكم العقول ،

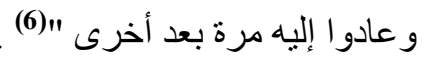

وجاء في الأشباه و النظائر : " العادة عبارة عما يستقر في النفوس من الأمور

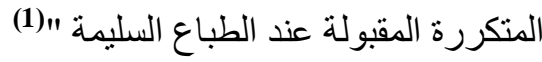

انظر مادة ( عرف ) في : لسان العرب (236/9) ، معجم مقاييس اللغة (173/3 281) ، القاموس .

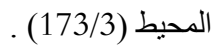

. (239/9)

شرح تتقيح الفصول ( 448) .

التقرير والتحبير (282/1) .

الجرجاني هو : علي بن محمد بن علي ، فيلسوف من كبار العلماء بالعربية ، له مصنفات منها :

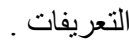

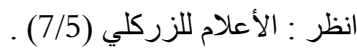

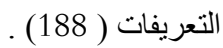




$$
\text { د/ شريفة بنت علي الحوشاني }
$$

و عند ابن أمير الحاج(2) (ت 879هـ) هو : " الأمر المتكرر من غير علاقة عقلية"(3)

أجده أخذ تعريف ابن الهمام و أبدل لفظ " شرعية " بـ " عقلية " لأن الثرعية تخرج

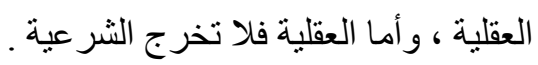

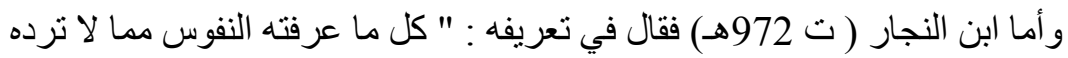

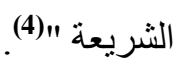

و الذي أر اه راجحاً من التعريفات ما ذهب إليه ابن النجار _ ـ الله تعالى أعلم.

\section{الفرق بين العرف والعادة :}

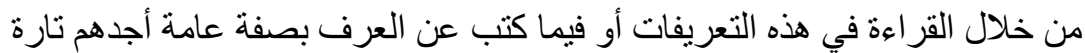

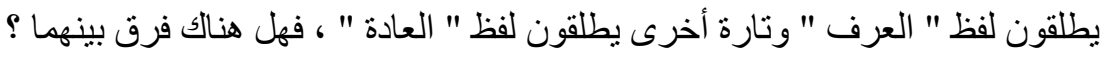

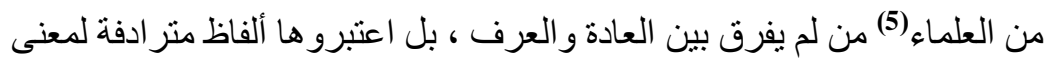

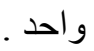

ومنهم من فرق بينهما فأطلق العرف على العرف القولي ، و العادة على العرف الفعلي

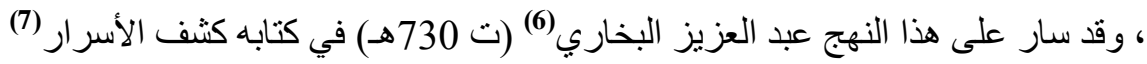

الأشباه و النظائر لابن نجيم (93) .

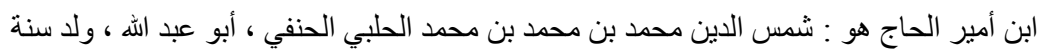

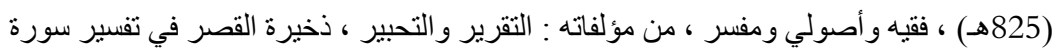

$$
\begin{aligned}
& \text { الظر : سير أعلام النبلاء (285/5) ، الأعلام (278/7) . } \\
& \text { التقرير والتحبير (282/1) . } \\
& \text { شرح الكوكب المنير (448/4) . }
\end{aligned}
$$

انظر : المستصفى (111/1) ، شرح الكوكب المنير (448/4) ، شرح تنقيح الفصول (448) ،

الأثباه والنظائر لابن نجيم ( 93 ) ، المو افقات (285/2) ، المسودة (124/11) ، الأثباه و النظائر

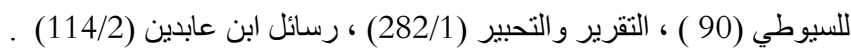

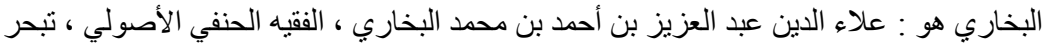

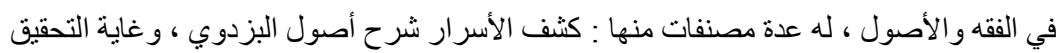




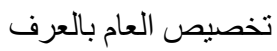

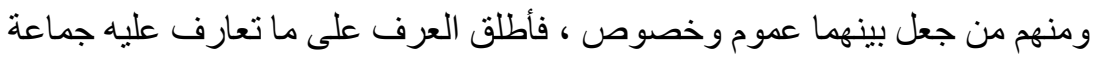

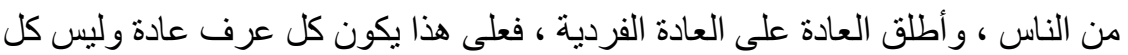

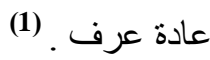

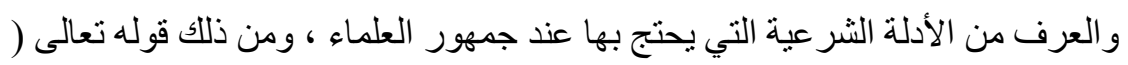

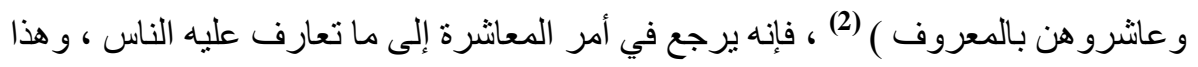
يختلف من زمن إلى زمن .

وكذا قوله صلى الله عليه وسلم لهند : " خذي ما يكفيك وولاك بالمعروف "(3) ، ، أمر ها بأن

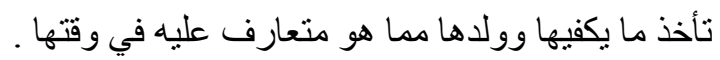

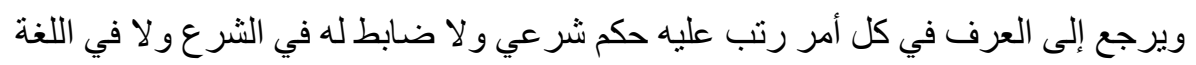

ومن ذللك : إحياء الأرض الموات ، الحرز في السرقة ، و انتفاع المستأجر بما جرت به العادة

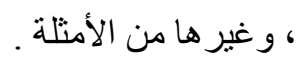

انظر : المدخل الفقهي للزرقاء (841/2) ، أصول مذهب الإمام أحمد (524) .

سورة النساء ، الآية رقم ( 19 ) .

جزء من حديث صحيح ، أخرجه البخاري في صحيحه بحاثنية السندي (160/4) ومسلم في

صحيحه بشرح النووي (7/12) .

انظر : شرح الكوكب المنير ( 448/4) ، الأشباه والنظائر للسيوطي (90) . 


\section{د/ شريفة بنت علي الحوشاني \\ المطلب الثالث \\ تعريف التخصيص وحكمه}

\section{التخصيص في اللغة :}

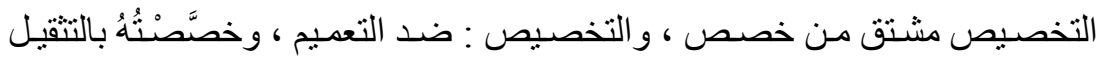

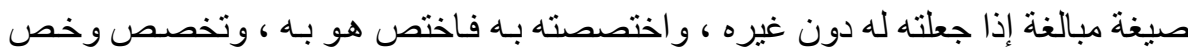

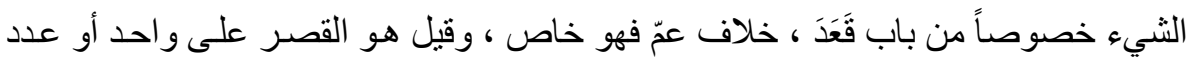
معلوم (1)

\section{التخصيص في الاصطلاح :}

عند أبي الحسين البصري ( ت 436هـ) هو : " إخراج بعض مـا تناولـه الخطاب مـع

كونه مقارناً له ويدخل في ذللك إخر اج و احد من النكر ات "(2).

و عند أبي يعلى ( ت 458هـ) هو : " تمبيز بعض الجملة بحكم "(3).

و أما الثيرازي (ت476هـ ) فقال التخصيص هو : هو " تمييز بعض الجملـة مـن الجملة أو معنى " (4)، ثم قال : " و أما تخصيص العموم فحده : إخر اج بعض ما دخل في اللفظ العـام

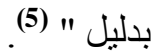

و عند الرازي (ت 606هـ) : " إخر اج بعض ما تناوله الخطاب عنه " (6).

و عند الآمدي ( ت 631هـ ) هو : " استعمال اللفظ في بعض محامله دون البعض "(7) :

(7)!

و أما ابن الحاجب ( ت 646هـ ) فقال هو : " قصر العام على بعض مسمياته ابتداء "

انظر مـادة ( خصص ) في : المصباح المنير ( 171 ) ، الصـاح ( 1037) ، لسـان العرب (

$$
\begin{aligned}
& \text { المعتمد (234/1) . } \\
& \text { العدة (155/1) . } \\
& \text { شرح اللمع (341/1) . } \\
& \text { شرح اللمع (341/1) . } \\
& \text { المحصول (396/1) . } \\
& \text { الإحكام في أصول الحكام (396/1) . } \\
& \text { مختصر المنتهى بشرح العضد (129/2) . }
\end{aligned}
$$


و عند القر افي (ت 684هـ) هو : " إخر اج بعض مـا يتناو لـه اللفظ العام ، أو مـا يقوم

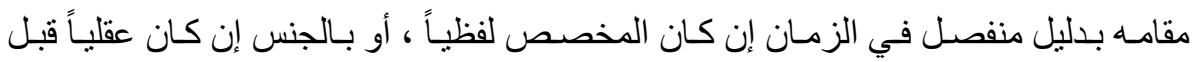

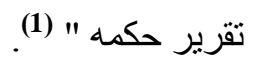

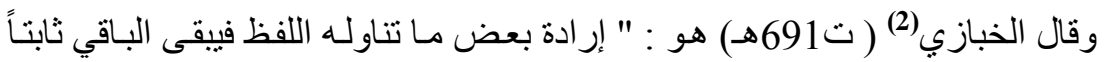
بذلك النظم بعينه " (3)

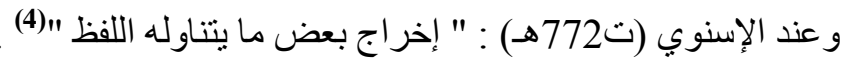

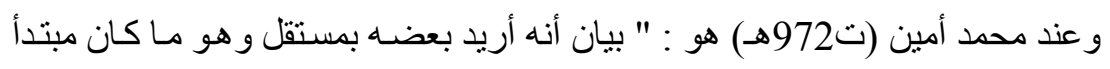
بنفسه غير متعلق بصدر الكلام "(5).

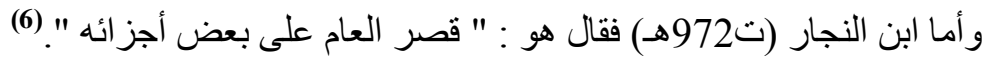

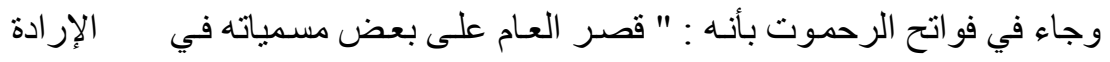

وقال الثوكاني (8) (ت 1250هـ) : " إخر اج بعض مـا كان داخلاً تحت العموم على

تقدير عدم المخصص ". (9)

وبالنظر إلى التعريفات السابقة أجد بعض العلماء من اختار تعريف إمامه في المذهب

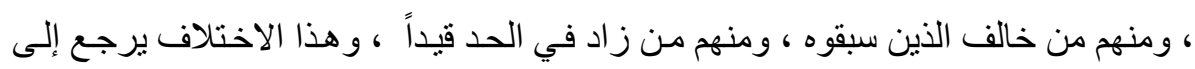

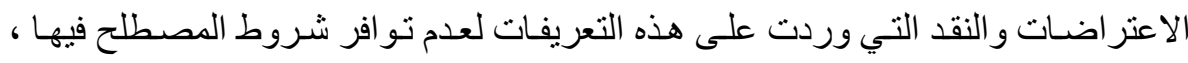

شرح تنقيح الفصول (51) .

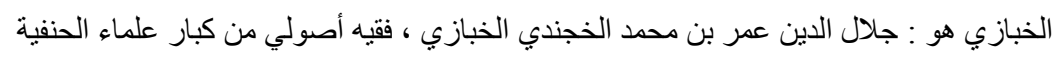

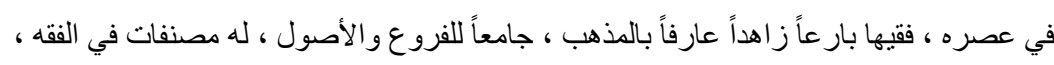

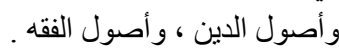
انظر : الفو ائد البهية (151) ، الجوله اهر المضية (398/1) .

$$
\text { تهرية المغني (261) . }
$$

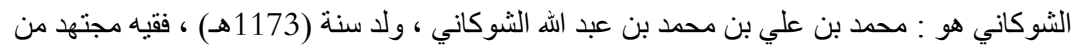

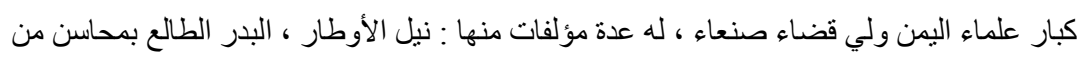

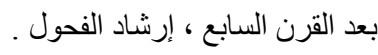

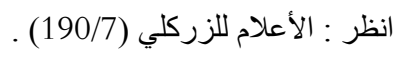

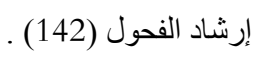




$$
\text { د/ شريفة بنت علي الحوشاني }
$$

و هذه التعريفات و إن اختلفت في الألفاظ فإنها متقاربة في المعنى ، ولعل التعريف المختار هو

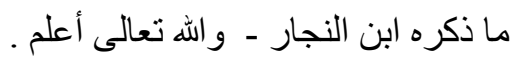

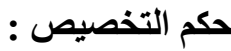

يجوز التخصيص مطلقاً عند الأئمة الأربعة وجمهور العلماء (1)، سواء كان العام أمراً أمراً أو نهياً أو خبراً ، وقد شذ بعضهم في الخبر (2) ، وحكى بعض العلماء الخلاف في الأمر

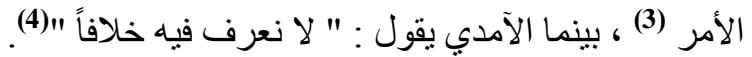

\section{الأدلة على جواز التخصيص :}

دل الشرع و العقل على جواز تخصيص العام ومن تللك الأدلة :

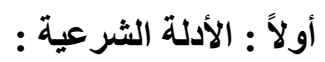

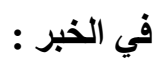

قوله تعالى : ( ما تذر من شيء أتت عليه إلا جعلته كالرميم ) (5)، وكذا قوله تعـالى (

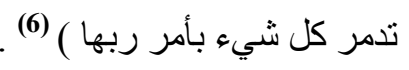

وجه الدلالة : أنها أتت على كل شيء ولى وعلى الأرض و الجبـال و السموات ولم تدمر ها

أو تجعلها رميماً.

وقوله تعالى : ( و أوتيت من كل شيء )

انظر : المستصفى (98/2) ، الإحكام للآمدي (487/1) ، مختصر ابن الحاجب (130/2) ، فواتح

الرحموت (300/1) ، شرح الكوكب المنير (269/3) ، إرشاد الفحول (143) .

انظر : المعتمد (255/1) ، العدة (595/2) ، اللمع (18) ، التبصرة (143) ، المحصول (398/1)

، الإحكام للآمدي (487/1) ، المسودة (130 ) ، مختصر البعلي (116) ، كثف الأسرار للبخاري

(307/1) ، فو اتح الرحموت (301/1) ، تيسير التحرير (275/1) ، شرح الكوكب المنير (267/3)

انظر : المحصول (398/1) ، فواتح الرحموت (301/1) ، شرح الكوكب المنير (269/3) .

$$
\text { الإحكام في أصول الأحكام (488/1) . }
$$

سورة الذاريات الآية رقم ( 42 ) ) .

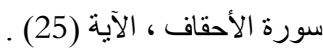

انظر : المستصفى (98/2) ، الإحكام للآمدي (487/1) ، شرح تنقيح الفصول (51) ، المهذب للنملة

. (1596/4)

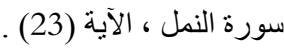




$$
\text { تخصيص العام بالعرف }
$$

وجه الدلالة : أنها لم تؤت السموات والأرض وملك سليمان . في الأمر (2) : (2)

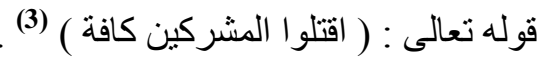

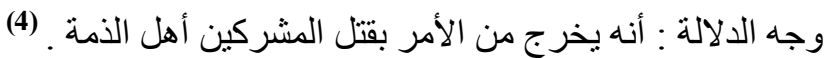

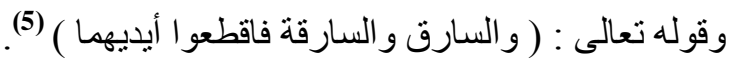

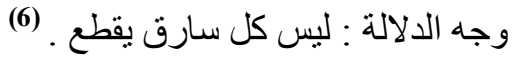

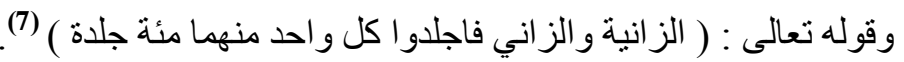

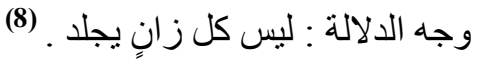

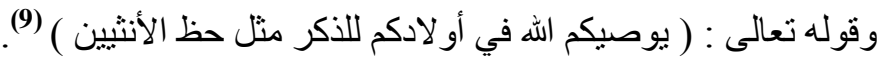

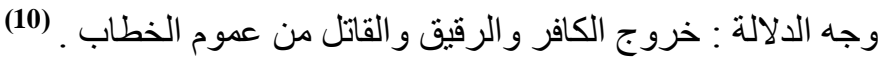

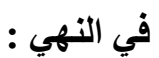
قوله تعالى : ( و لا تقربو هن حتى يطهرن ) (11).

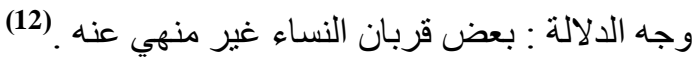

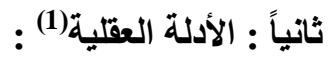

انظر : المعتمد (255/1) ، المستصفى (2/2 98) ، الإحكام للآمدي (485/1) ، مختصر المنتهى

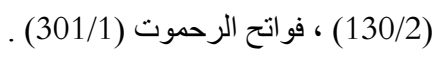

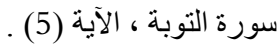

انظر : شرح اللمع ( 341/1) ، المستصفى (98/2) ، الإحكام للآمدي (488/1) .

$$
\text { سورة المائدة ، الآية (38) . }
$$

انظر : المستصفى (98/2) ، الإحكام للآمدي (488/1) ، المهذب (1596/4).

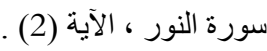

انظر : المستصفى (98/2) ، الإحكام للآمدي (488/1) ، المهذب (1596/4).

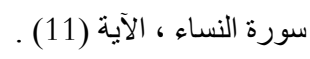

انظر : المستصفى (98/2) ، الإحكام للآدمي (488/1) ، المهذب (1569/4) .

$$
\text { سورة البقرة ، الآية (222) . }
$$




$$
\text { د/ شريفة بنت علي الحوشاني }
$$

لا معنى لتخصيص العموم سوى صرف اللفظ عن جهة العهوم الذي هو

حقيقة فيه إلى جهة الخصوص بطريق المجاز .

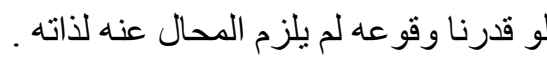

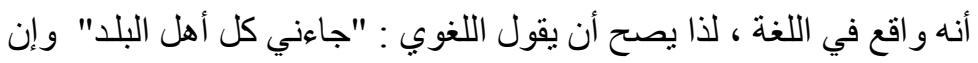

تخلف عنه بعضهم .

وبعـد أن عـرف معنـى التخصـيص وحكمـهـ عنـد العلمــاء ، أجـــ أن القـائلين بجـواز

التخصيص اختلفو ا فيما بينهم في مخصصات العموم ، والتي منها تخصيص العام بالعرف أو ما يسميه البعض العادة وسيأتي التفصيل فيه إن شاء الله تعالى . 


\section{تخصيص العام بالعرف}

\section{المبحث الثاني : تخصيص العام بالعرف}

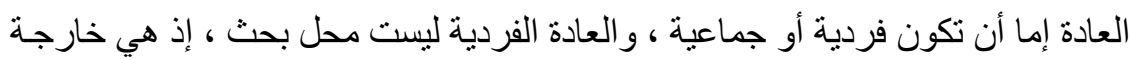

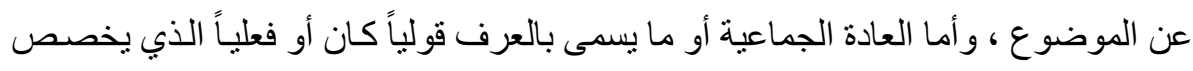

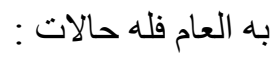

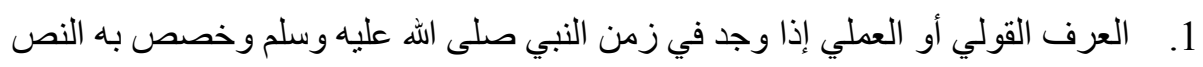

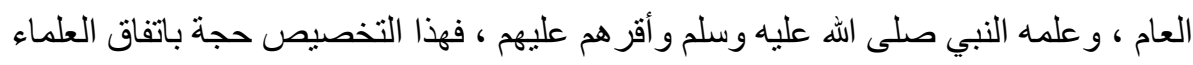

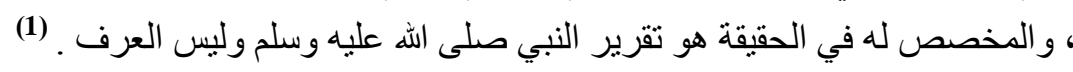

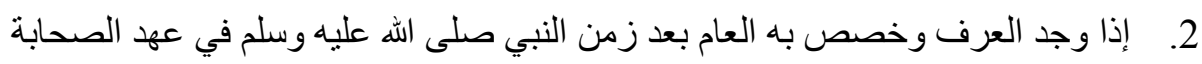

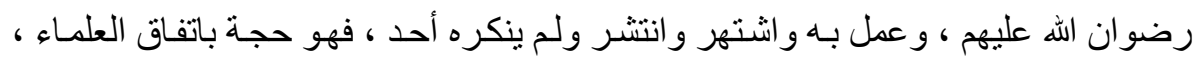

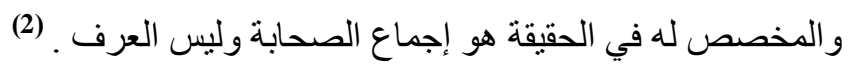

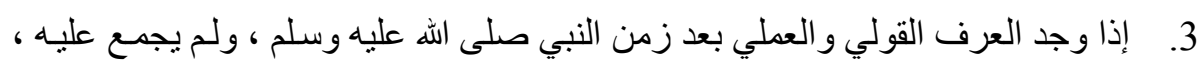

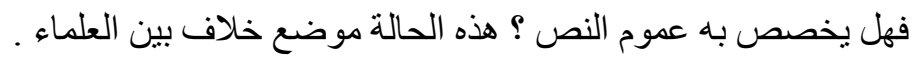

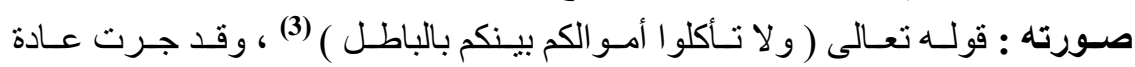

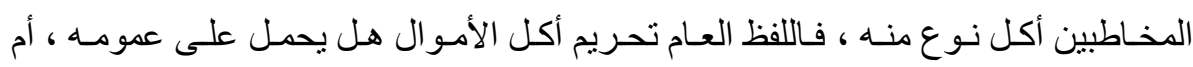

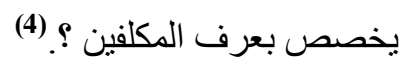

وكذا لو كان من عادة المخاطبين تتـاول طعام خاص فورد خطساب عام بتحريم الطعام

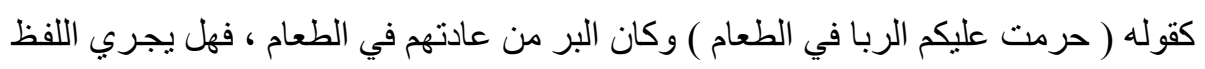

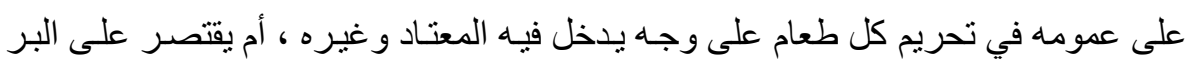

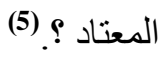
اختلف العلماء في ذلك على مذاهب :

انظر : شرح تنقيح الفصول (211) ، نهاية السول (469/2) ، التقرير و التحبير (282/2) ، مسلم

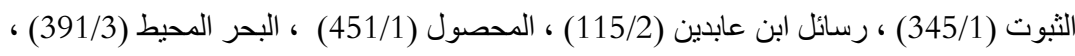

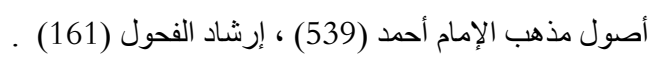
انظر : المحصول (451/1) ، البحر المحيط (5391/3) ، إنشاد لفحل (161/) ، ميزان الأصول (164) ، إرشاد الفحول

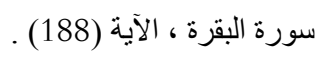

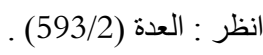

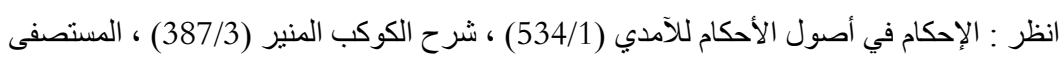

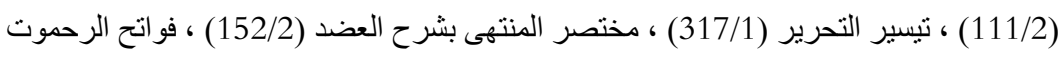




$$
\text { د/ شريفة بنت علي الحوشاني }
$$

المـذهب الأول : ذهـب جمهور الحنابلـة و الثــافعية وبعض المالكيـة إلىى أنـه لا يعتبر

$$
\text { مخصصاً و لا يحتج به . }
$$

يقول الثير ازي (ت476هـ) : " فأما العرف و العادة فلا يجوز تخصيص العموم بـه لأن

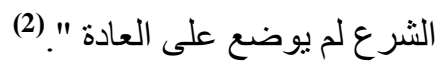

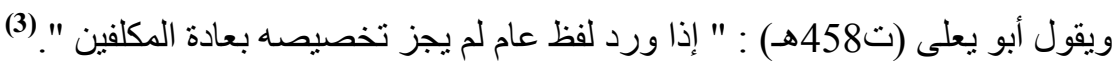

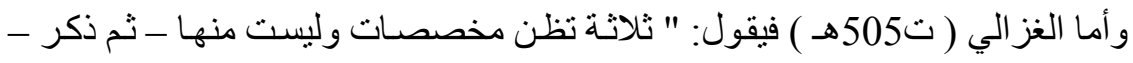

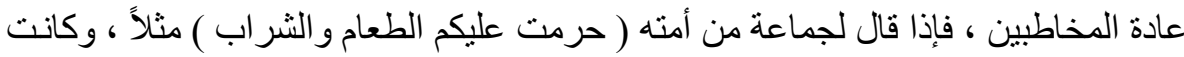

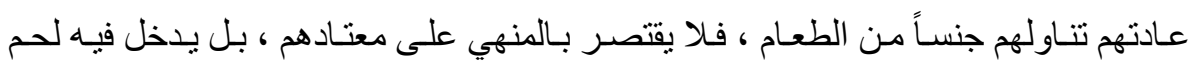

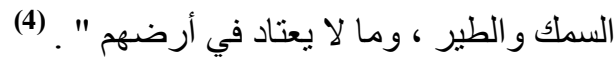

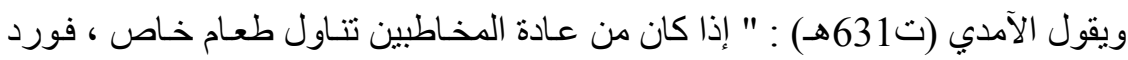

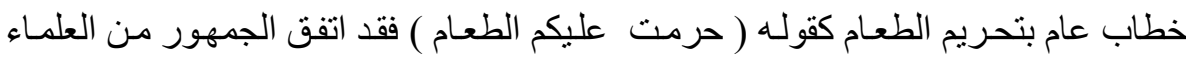

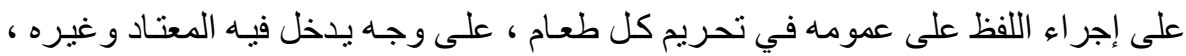

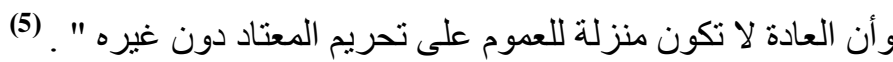

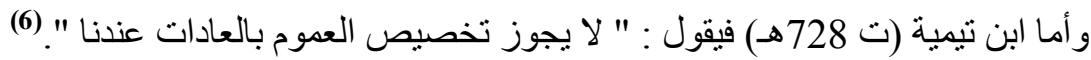

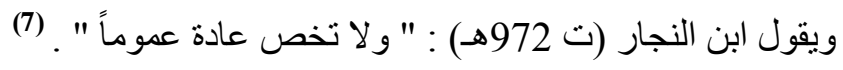

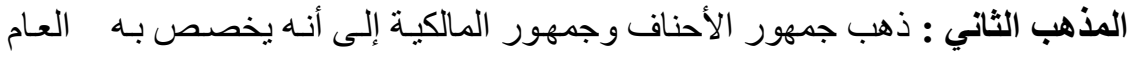

ويحكي القر افي (ت684هـ) مذهب المالكية : " و عندنا العو ائد مخصصـة للعدوم ، قـال

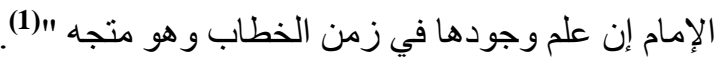

انظر : المعتمد (278/1) ، المستصفى (111/2) ، الإحكام للآمدي (534/1) ، شرح الكوكب المنير

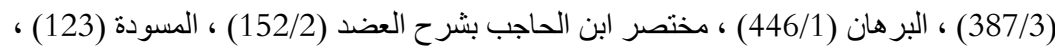
العدة (593/2) ـ شرح اللمع (391/1) ، المحصول (451/1) ، البحر المحيط (392/3) ، (392/3) .

$$
\begin{aligned}
& \text { شرح اللمع (391/1) . } \\
& \text { العدة (593/2) . } \\
& \text { السنصفى (111/2) . } \\
& \text { الإحكام (534/1) . } \\
& \text { المسودة (123) . } \\
& \text { شرح الكوكب الكنير (123) (387/3) . }
\end{aligned}
$$

انظر : مختصر المنتهى بشرح العضد (3152/2) ، شرح تنقيح الفصول (211) ، (217) ، تيسير التحرير

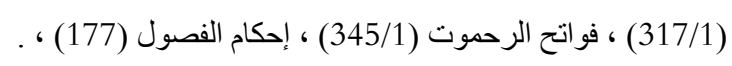




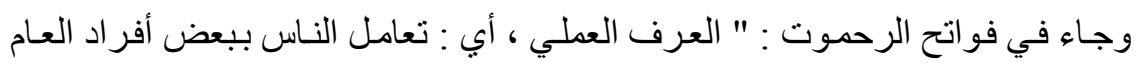

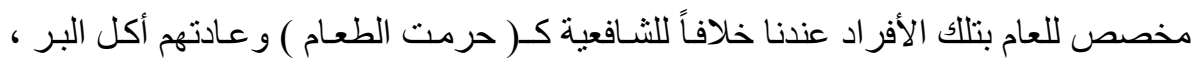

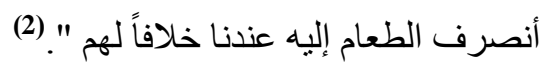

ويقول محمد أمين (ت ت972هـ) : " العادة وهي الأمر المتكرر ولو من غير علاقاقة عقلية

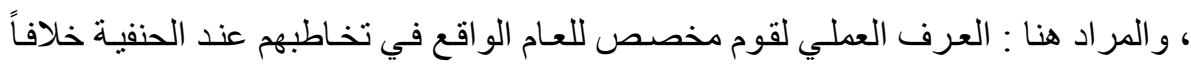

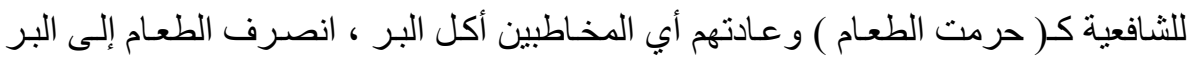

المذهب الثالث : ذهب أصحاب هذا المذهب إلى التفصيل(4) ، و هو أنه يجوز تخصيص

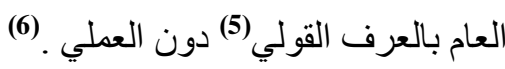

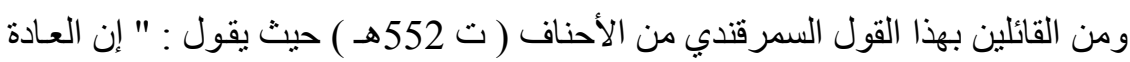

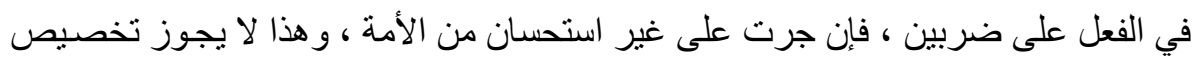

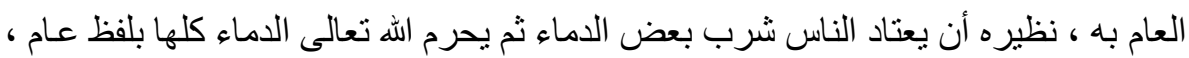

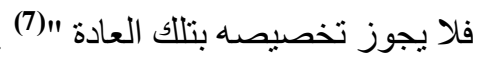

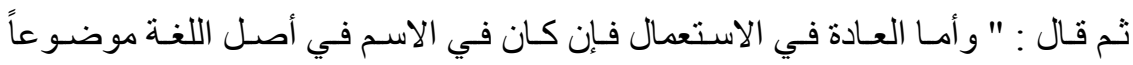

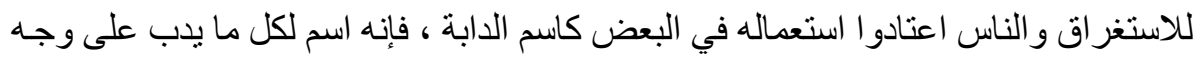

شرح تنقيح الفصول (211) . (345/1) ( ) . (2)

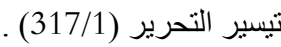

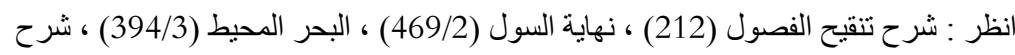
الكوكب المنير (387/3) ، إرشاد الفحول (161) .

وقد علق ابن تيمية (ت 728هـ) على تخصيص العام بالعرف القولي بقوله : " إن العرف في اللغة العة العيد

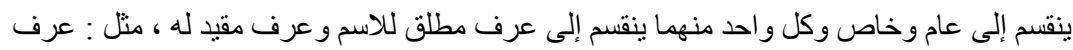

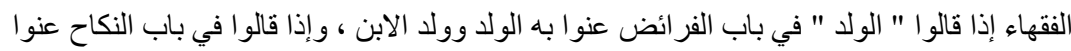

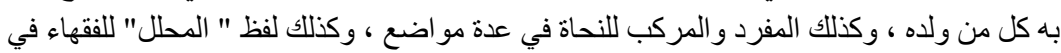

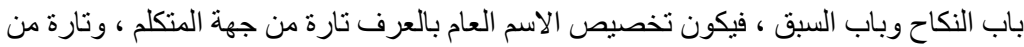

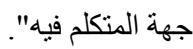
أورد ابن تيمية (ت 728هـ) اعتر اض على هذا التفصيل فقال : "وفيه نظر " .

$$
\text { انظر : الدسودة (123) . }
$$




\section{د/ شريفة بنت علي الحوشاني}

الأرض ، و الناس تعارفوا استعماله في الفرس فلو تعبدنا الله تعالى بشيء في الدابـة ينصرف

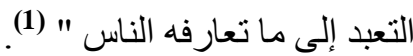
فالسمرقندي يفرق هنا بين العرف القولي و الفعلي ، فيجيز تخصيص العام بـالقولي دون

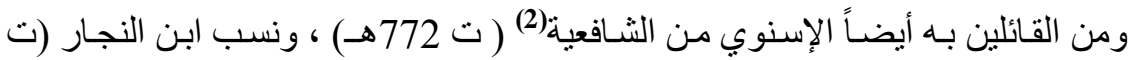

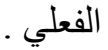

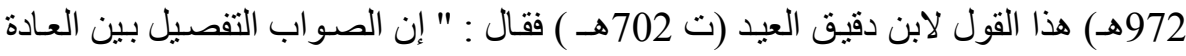

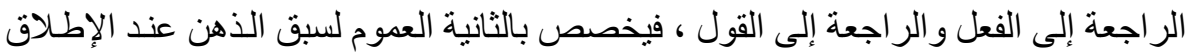

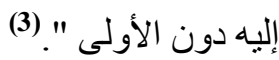

وقد فرق القر افي (ت684هـ ) بين العادة السـابقة على العدوم فتكون مخصصـة ، وبـين

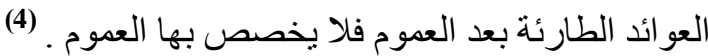

وفرق أيضاً بين العرف القولي والفعلي حيث قال : " إن العو ائد القولية تؤثر في الألفاظ

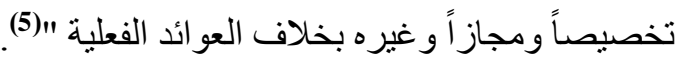

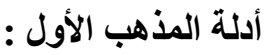

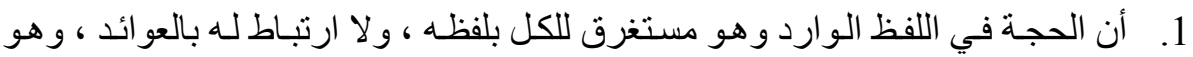

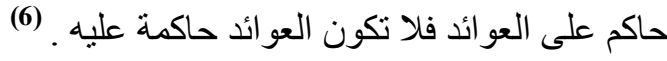

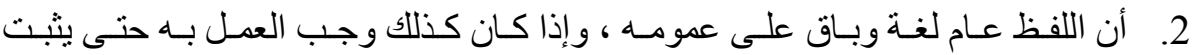

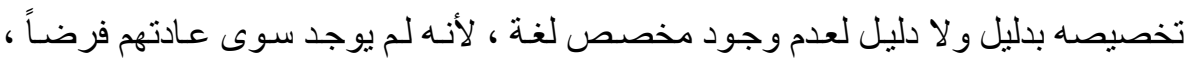

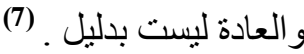

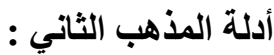

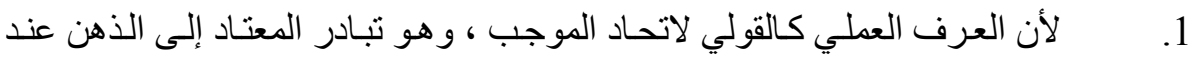

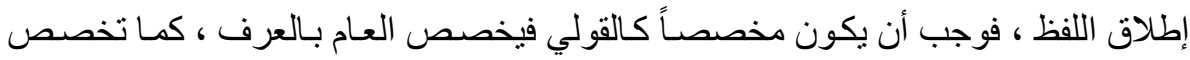

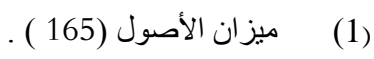

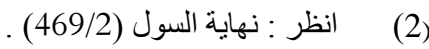

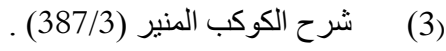

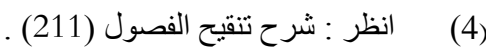

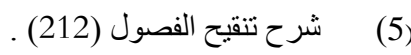

(6) انظر : العدة (594/2) ، المستصفى (1611/2) ، الإحكام في أصول الأحكام للآمدي (534/1) ، إرشاد

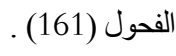

انظر : العدة (594/2) ، مختصر ابن الحاجب بشرح العضد (152/2) ، ، المسودة (124) ، البحر

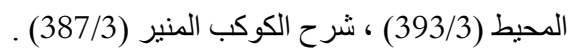


الدابة بذو ات الأربع ، بعد كونه في اللغة لكل ما يدب، وكما يتخصص النقد بالنقد الغالب في

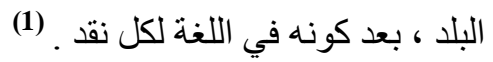

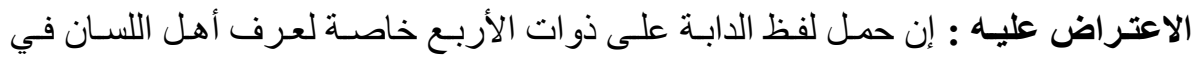

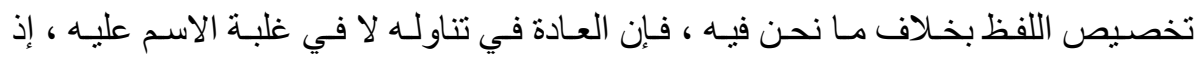

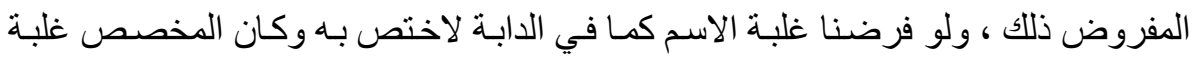

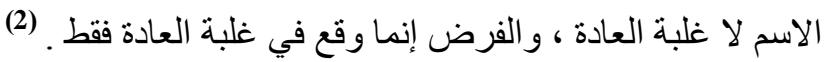

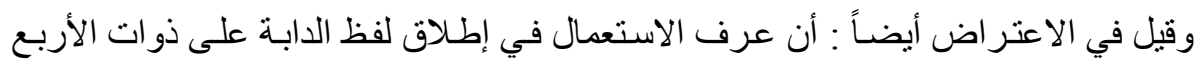

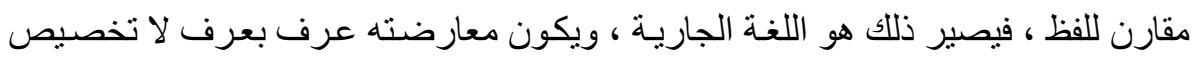

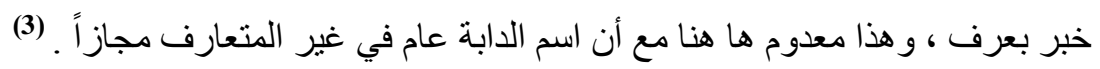

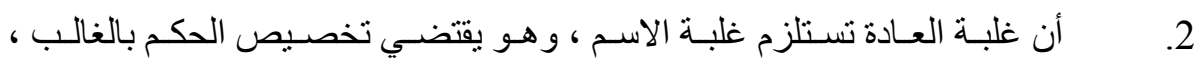

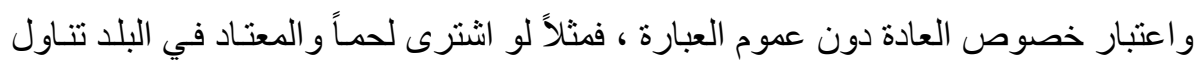

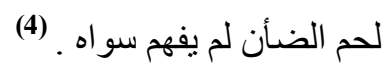

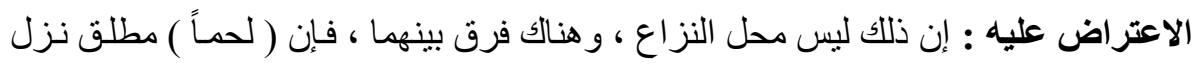

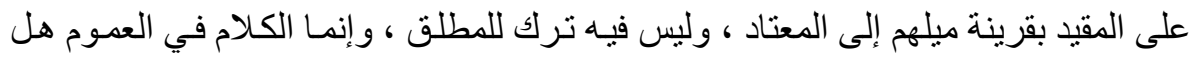

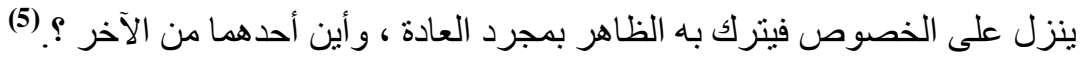

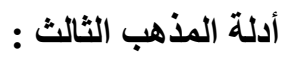

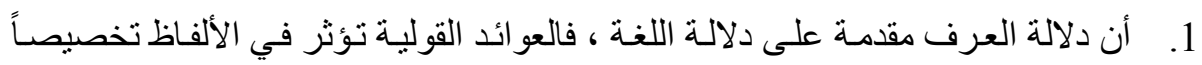

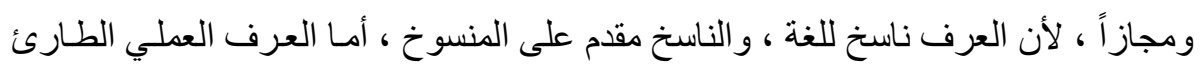

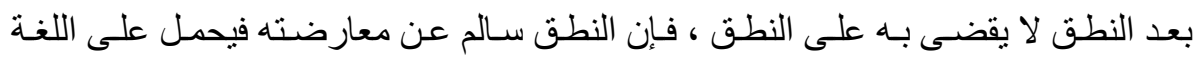

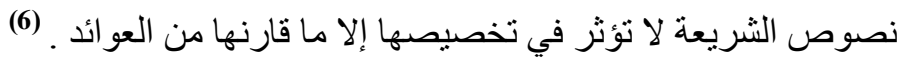

انظر : تقويم الأدلة (127) ، مختصر ابن الحاجب بشرح العضد (152/2) ، ، فو اتح الرحموت ، (317/1) ،

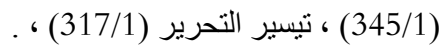

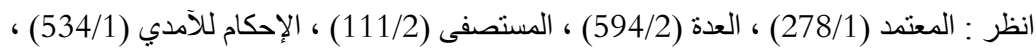
مختصر المنتهى (152/2) ، البحر المحيط (278/1)، لطذة (394/3) .

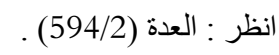

انظر : مختصر المنتهى (152/2) ، فو اتح الرحموت (345/1) ، تيسير التحرير (317/1) .

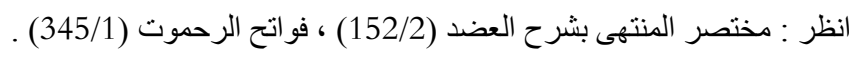
انظر : شرح تتقيح الفصول (211) . 


$$
\text { د/ شريفة بنت علي الحوشاني }
$$

2. تسابق الذهن عند الإطلاق إلى العرف القولي دون العملي فيخصص العموم بـالعرف

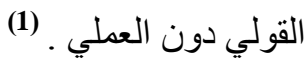

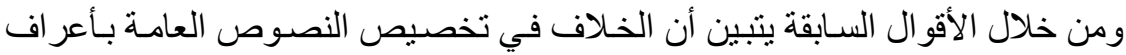

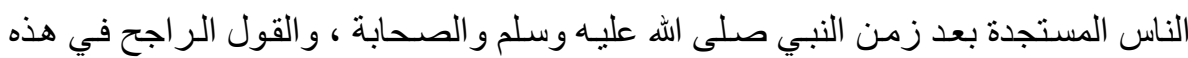

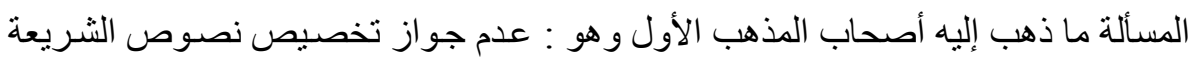

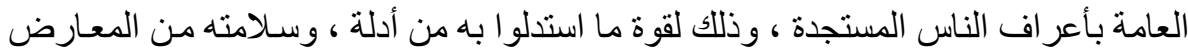

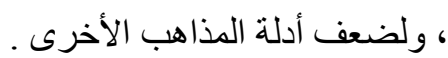
و أما تخصيص العمومات التي تجري بين الناس في معاملاتهم و عقودهم و أيمانهم بما التها

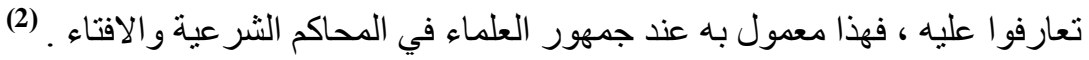

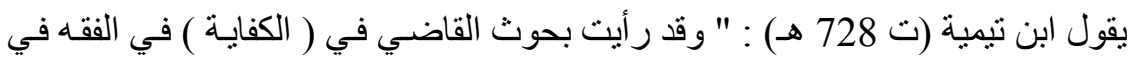

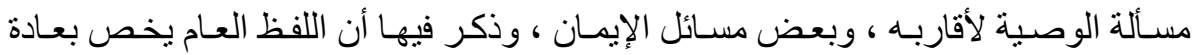

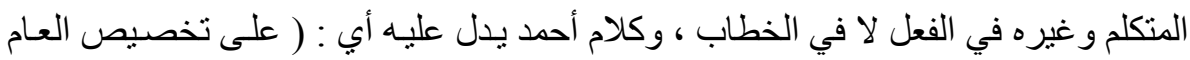

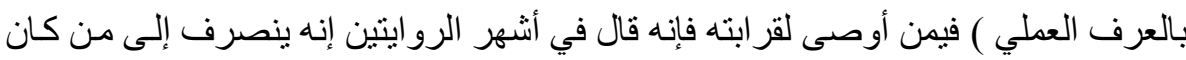

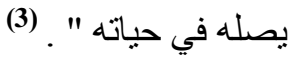




\section{تخصيص العام بالعرف \\ المبحث الثالث \\ تطبيقات فقهية لأثر الخلاف الثبد}

كان لخلاف العلماء في مسألة تخصيص العـام بـالعرف أثر في الفروع الفقهية ومن ذلك :

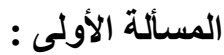

إذا خرج ما لا يعتاد خروجه من السبيلين ، كالحصى و الدود فهل هو ناقض للوضوء ؟ الأل

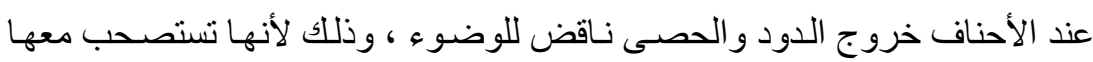

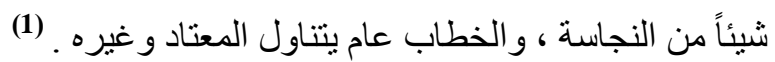

$$
\text { وللمالكية(2) ثلاثة أقو ال : }
$$

1. لاوضوء عليه خرجت الحصاة أو الدودة نقية أو غير نقية وهو المشهور في المذهب

$$
\text { 3 }
$$

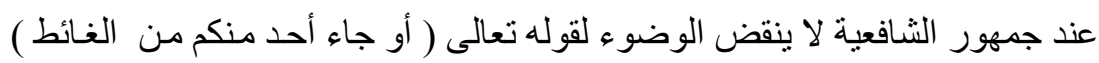

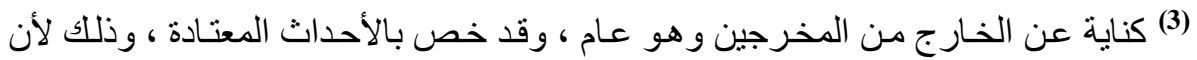

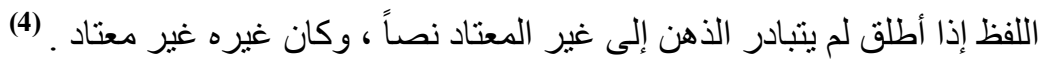

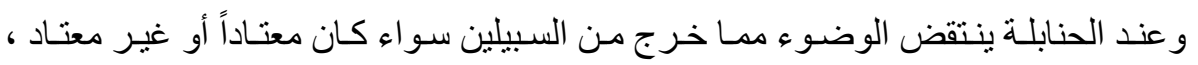

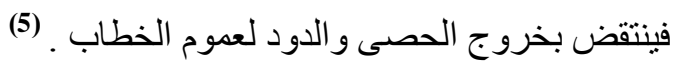

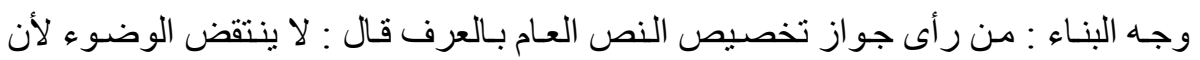

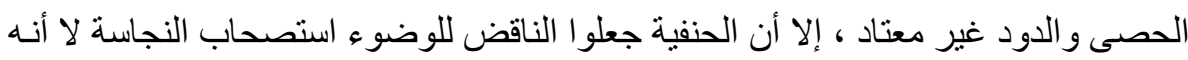

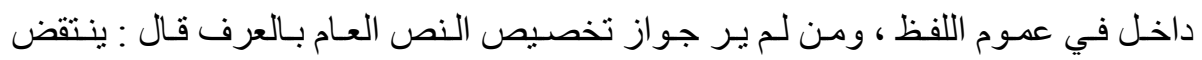

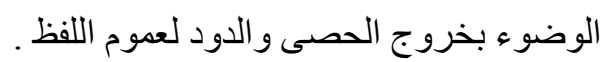

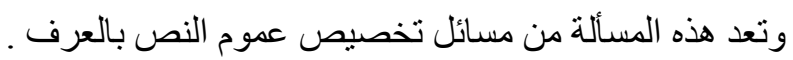

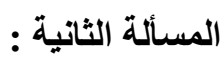

انظر : تبييين الحقائق للزيلعي (7/1) .

انظر : حاثية الدسوقي على الثرح الكبير (115/1) .

سورة النساء الآية (43) .

$$
\text { انظر : البحر المحيط ( 395/3) . }
$$

انظر : كثاف القناع عن منن الإقناع (122/1) ، الثحطر ( الثرح المتع (269/1 ،270) . 


$$
\text { د/ شريفة بنت علي الحوشاني }
$$

من حلف ألا يأكل بيضاً أو رؤوساً فأكل بيض سمك أو رؤوس عصافير ، فهل يحنث

عند الأحناف لا يحنث إلا بر أس الغنم ، و لأنها لا تسمي بيضـاً أو رؤوسـاً إلا مقرونـة

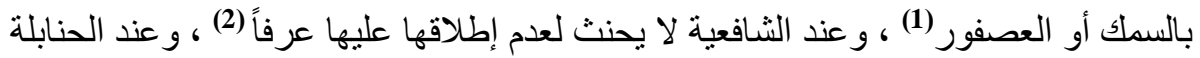

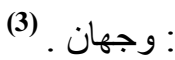

وجـه البنـاء : أن من خص عموم اللفظ بـالعرف قال : لا يحنث ، و ومن لم ير جواز التخصيص قال : يحنث لعموم اللفظ ، و هذه المسألة مما يجرى بين النساس في الأيمان وليس

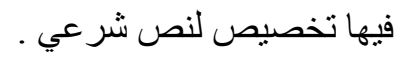

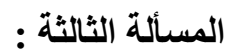

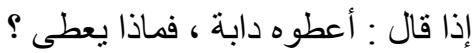

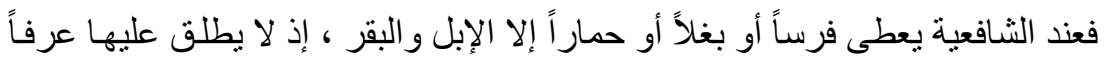

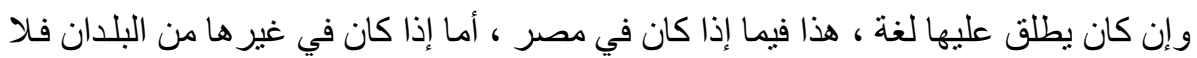

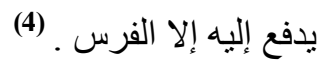
وجه البناء : من أجاز تخصيص عموم النص بالعرف ، خصها بما هو متعارف عليه

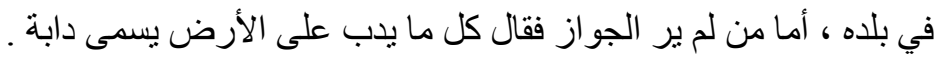

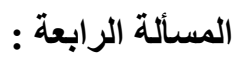

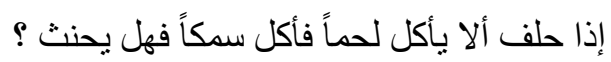

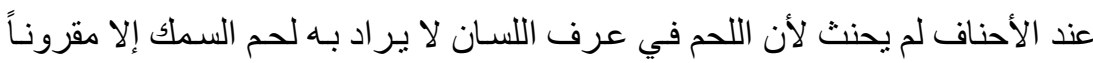

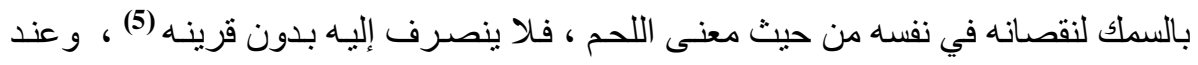

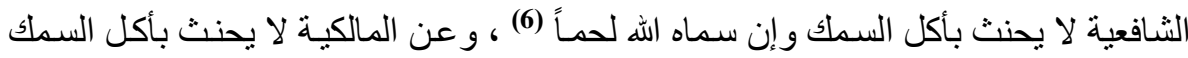

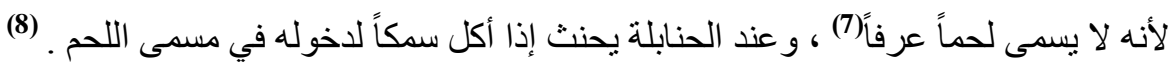

$$
\begin{aligned}
& \text { (1) انظر : تقويم الأدلة للابوسي (127) ، الأشباه و النظائر لابن نجيم (98) . }
\end{aligned}
$$

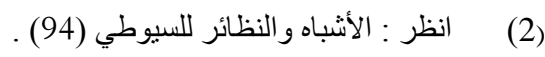

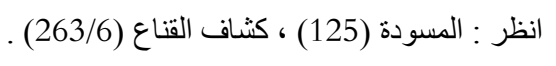

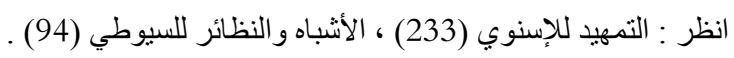

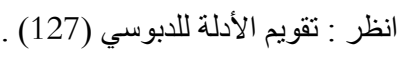

$$
\begin{aligned}
& \text { انظر : الأشباه والنظائر للسيوطي (93 الألفابوسي (127) . }
\end{aligned}
$$

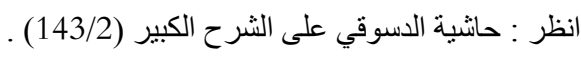

$$
\begin{aligned}
& \text { انظر : كثاف القناع (254/6) . }
\end{aligned}
$$




$$
\text { تخصيص العام بالعرف }
$$

وجه البناء : من قال بجواز تخصيص عموم اللفظ بالعرف قالو ال اليحنث بأكل السمك

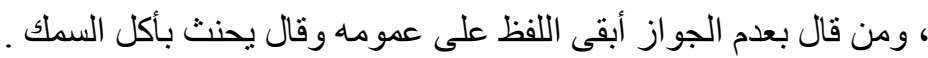

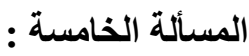

حلف ألا بأكل الخبز ، فأكل خبز الأرز أو خبز الاخن ، هل يحنث ؟

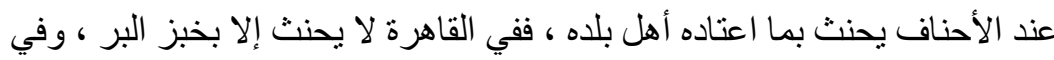

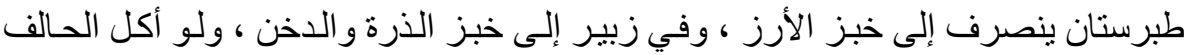

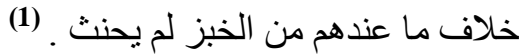

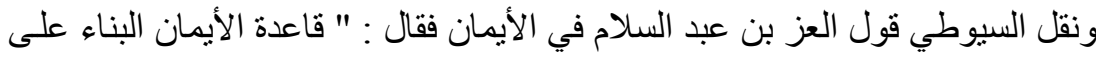

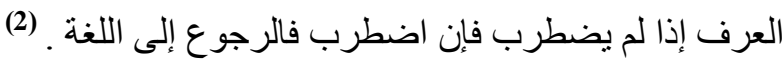

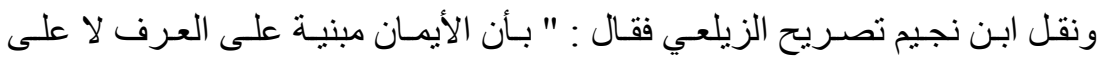

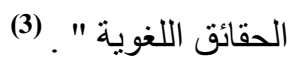

وقال ابن نجيم : " إذا تعارض العرف مع الثرع فدم عرف الاستعمال خصوصـاً في

(4) الأيمان .

ونقل السيوطي قول الر افعي : " تتبع اللغة تارة وذلك عند ظهور هـا وشمولها ، و هو

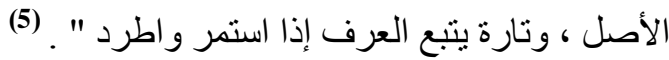

لذا فإن السيوطي ذهب إلى أن من أكل خبز أرز أو أو دخن يحنث إنى وإن لم يكن متعارفاً

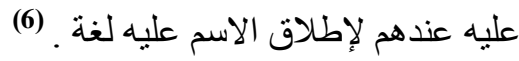

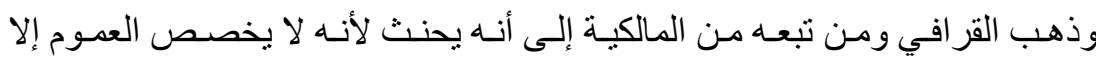

$$
\text { بالعرف القولي دون العملي . }
$$

وبعض المالكية قالو ا يخصص عموم الأيمان بالعرف القولي و الفعلي . (8)

$$
\begin{aligned}
& \text { (1) انظر : الأشباه و النظائر لابن نجيم (98) . }
\end{aligned}
$$

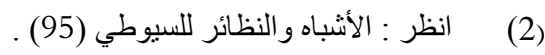

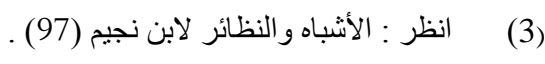

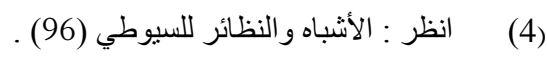

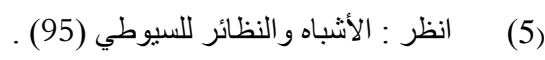

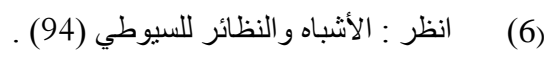

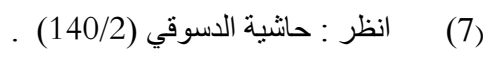

$$
\begin{aligned}
& \text { انظر :إحكام الفصول للباجي (177) ، حاثشية الدسوقي (140/2) . }
\end{aligned}
$$




$$
\text { د/ شريفة بنت علي الحوشاني }
$$

و عند الحنابلـة يحنث بأكل خبز الأرز و اللـخن و إن لـ يكن معتـاداً في بلدهم وذلك له

$$
\text { لتناول الاسم له . (1) }
$$

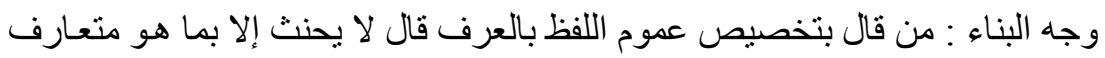

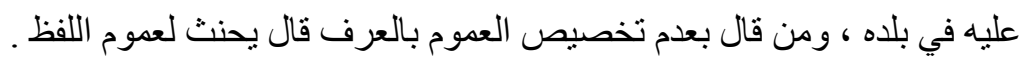

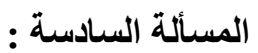

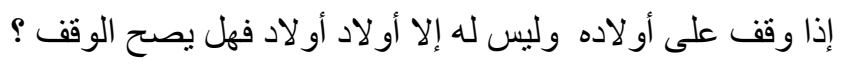

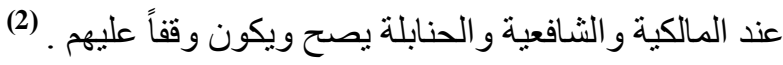

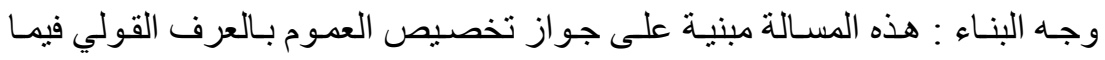

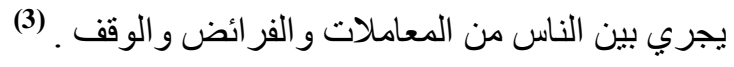




\section{خلاصة القول :}

من خلال ما تقدم من فروع فقهيـة يتضـح أن أغلب مـا ذكره العلمـاء من فروع فقهية

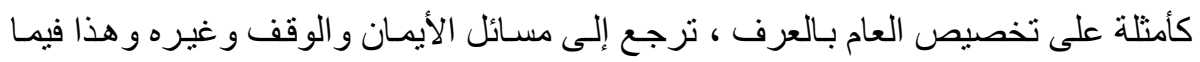
يجري بين الناس في معاملاتهم .

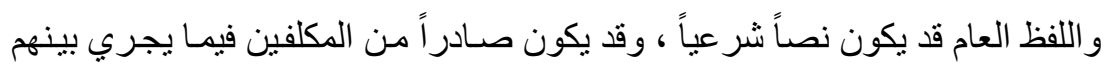

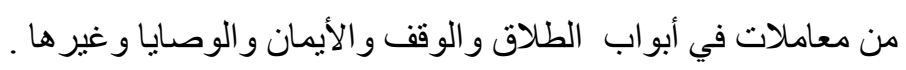

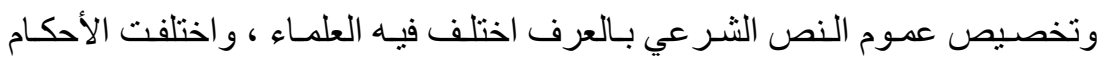

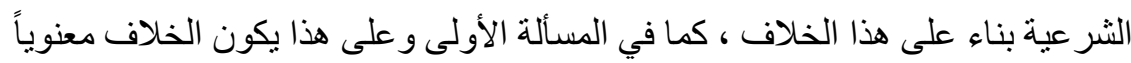

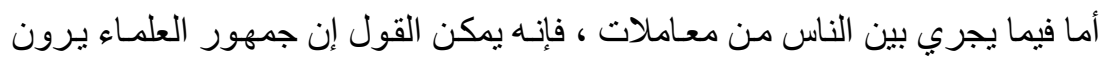

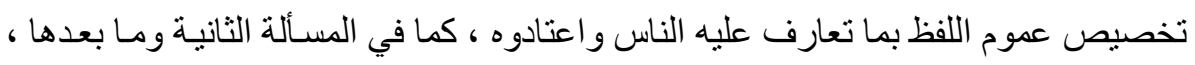

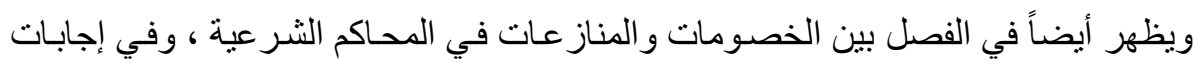

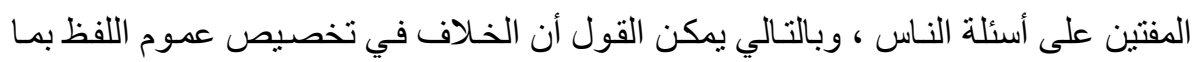

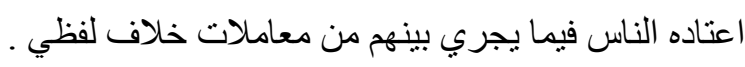




\section{د/ شريفة بنت علي الحوشاني}

\section{الخاتمة}

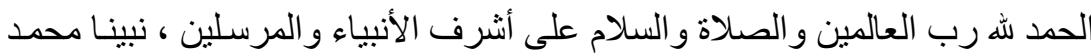
و على آله وصحبه أفضل صلاة وأتم تسليم ، أما بعد :

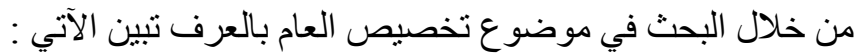
إن النص الثر عي قد يكون لفظه عاماً.

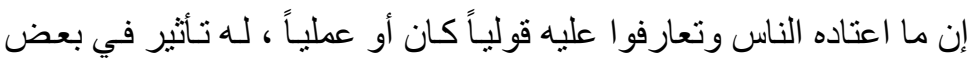

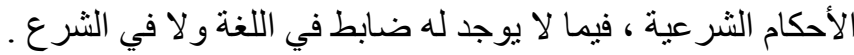
اتفق الأئمة الأربعة على جواز تخصيص النص العام سو اء كان العام أمراً أو نهياً أو خبراً . ( أو

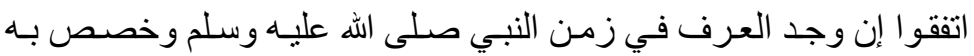
النص العام و أقر هم عليه النبي عليه السلام ، فالتخصيص هنا حجة و المخصص النص الحقيقي هو الهو

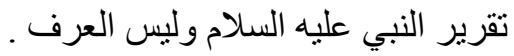

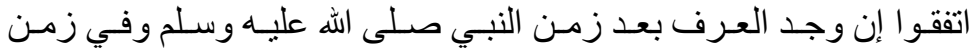

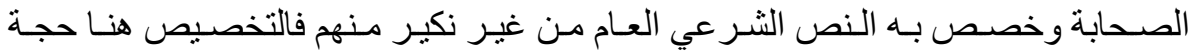
و المخصص الحقيقي هو إجماع الصحابة وليس العرف .

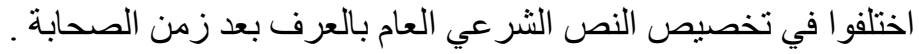
جمهور العلماء على عدم جواز تخصيص النص الثرعي بالعرف والخلاف في هذا معنوي .

جمهور العلماء على جواز تخصيص اللفظ العام بـالعرف فيما يجري بين

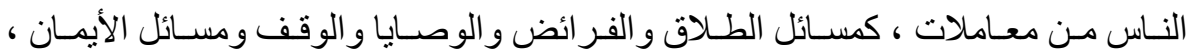

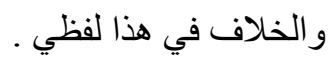
كما يلاحظ اختلاف مذهب الحنابلة في تخصيص العام بـالعرف فيما يجري بين الناس من

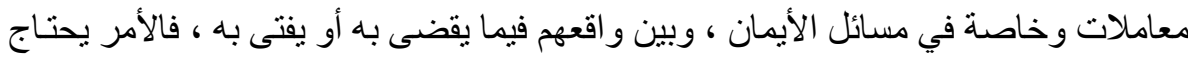

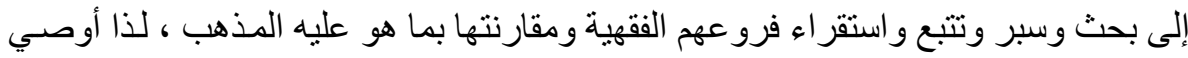

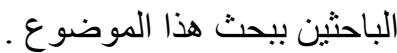

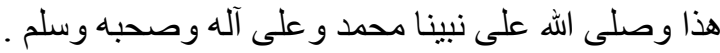

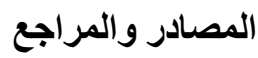




\section{تخصيص العام بالعرف}

1. الإحكام في أصـول الأحكام . لسيف الدين علي بن محمد الآمدي ، طبعة دار الكتب

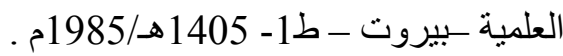

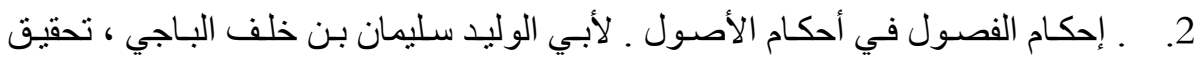

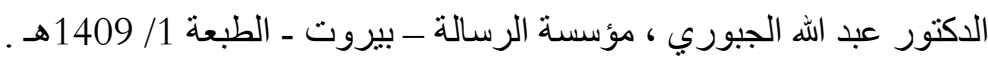
3. إرشاد الفحول إلى تحقيق الحق من علم الأصول ـ لمحمد بن علي الثوكاني ، طبعة دار الفكر . 4. الأشباه و النظائر في قو اعد وفروع فقه الثـافعية ـ لجـلال الدين السيوطي ، طبعة دار

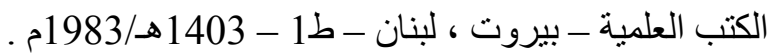
5. الأشباه و النظائر ـ لزين الدين بن إبر اهيم بن نجيم ، طبعة دار الكتب العلميـة ـ بيروت - لبنان - 1405 هـ/1985م . 6. أصول مذهب الإمـام أحمد ـ للدكتور عبد الله التركي ـ مطبعـة جامعـة عين شمس -

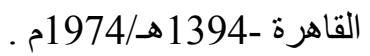
7. الأعلام ـ لخير الدين الزركلي ، طبعة دار العلم للملايين - بيروت - ط7 - 1974 - 1986م .

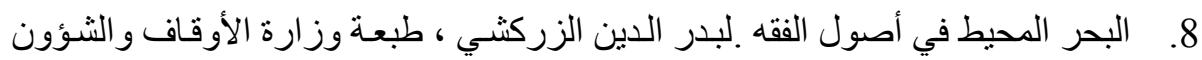

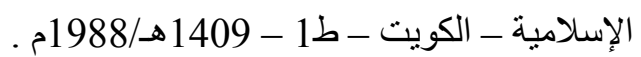

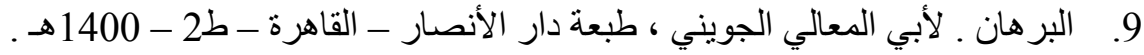

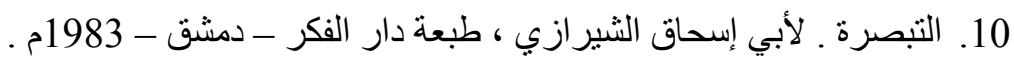

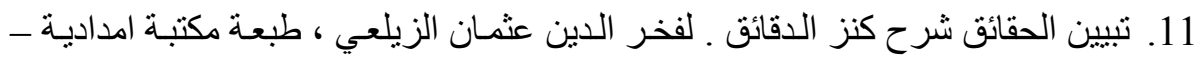
باكستان . 12. التعريفات ـ لعلي بن محمد الجرجاني ، طبعة دار الكتاب العربي - بيروت - ط2 1413هـ/1992م. 13. التقريـر و التحبيـر ـ لابـن أميـر الحساج ، طبعـة دار الكتب العلميـة ـ بيـروت - ط2 1403 هـ /1983م .

14. تقويم الأدلة في أصول الدين ـ لأبي زيد الدبوسي ، طبعة دار الكتب العلمية ـ بيروت -

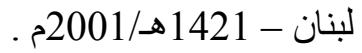

15. التمهيد في أصول الفقه ـ لأبي الخطاب الكلوذاني ، طبعة مركز البحث العلمي و إحياء

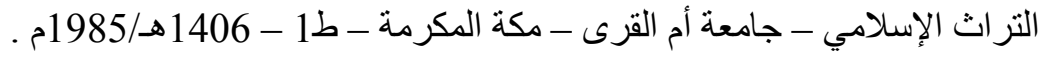

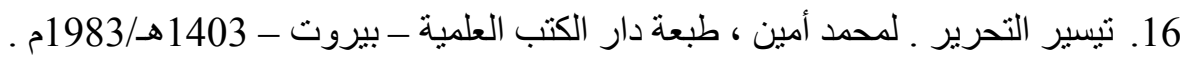

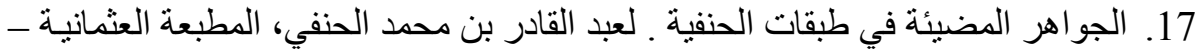




\section{د/ شريفة بنت علي الحوشاني}

18. حانثية الدسوقي على الثرح الكبير ـ طبعة دار الفكر .

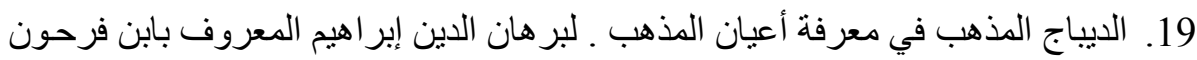

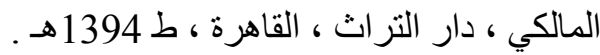

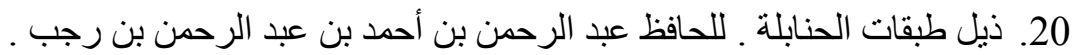

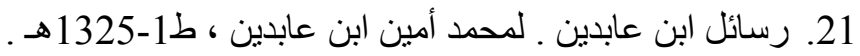

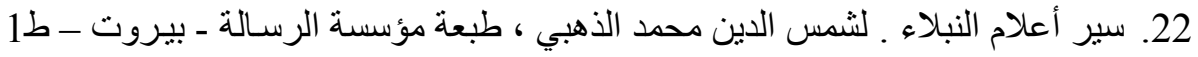
- 1405هـ/1985م ـ

23. شذرات الذهب في أخبار من ذهب ـ لأبي الفلاح عبدالحي بن العهـاد ، طبعة دار إحياء

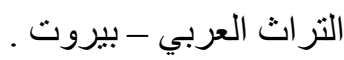
24. شرح تنقيح الفصول في اختصار المحصول ـ لثهاب الدين القرافي ، طبعة دار الفكر -

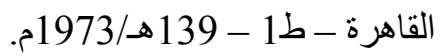
25. شرح الكوكب المنير ـ لمحمد بن أحمد الفتوحي ، طبعة جامعة أم القرى - مكة المكرمـة 1408هـ/1987م 26. شرح اللمع في أصول الفقه ، لأبي إسحاق الثيرازي ، طبعة دار الغرب الإسـلامي -

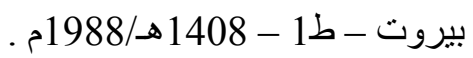
27. الصحاح تـاج اللغـة وصـاح العربيـة .لإسماعيل بن حمـاد الجو هري ،طبعة دار العلم للملايين - ط4 - 1407هـ/1987م. 28. صحيح البخاري بحانثية السندي ـ طبعة دار الثعب ـ القاهرة .

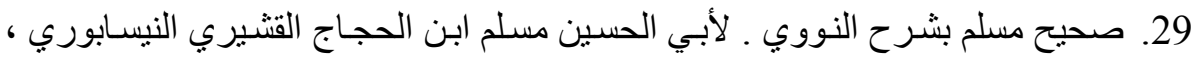

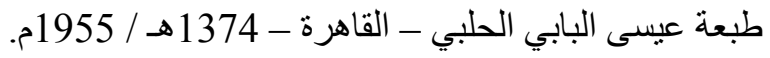
30. طبقات الحفاظ .محمد بن أحمد بن عثمان الذهبي ، طبعة دار الصميعي.

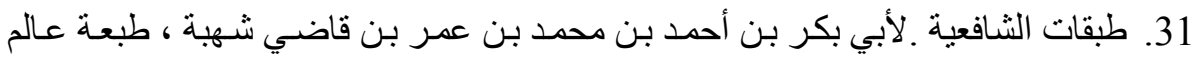

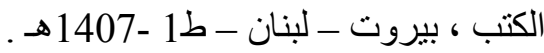

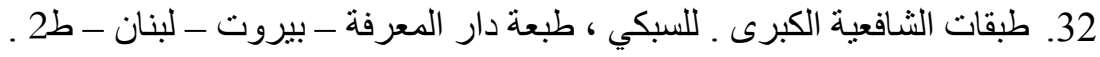
33. العبر في خبر من غبر ـ للحافظ شمس الدين الذهبي ، طبعة دار الكتب العلمية - بيروت 1405 هـ/1985م ـ

34. العدة في أصول الفقه ـ لأبي يعلى محمد بن الحسن البغدادي ، مطبعة المديني ـ القاهرة

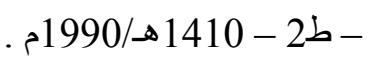
35. الفتح المبين في طبقات الأصوليين ـ لعبد الله المر اغي ، طبعة القاهرة . 


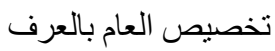

36. الفو ائد البهية في تراجم الحنفية . لمحمد بن عبد الحي اللكنوي ، مطبعة السعادة - ط11324 هـ .

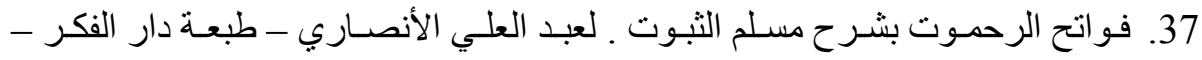
بيروت .

38. القاموس المحيط ـ لمحمد بن يعقوب الفيروز أبـادي ، طبعـة المؤسسـة العربيـة للطباعـة

$$
\text { والنشر - بيروت - لبنان . }
$$

39. كثاف القناع عن منن الإقناع ـ لمنصور بن يونس البهوتي ، عالم الكتب - بيروت لبنان .

40. كثف الأسرار عن أصول البزدوى ـ لعبد العزيز البخاري ، طبعة دار الكتاب العربي

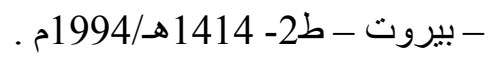

41. لسان العرب ـ لجمال الدين محمد بن مكرم بن منظور ، طبعـة دار الفكر - بيروت - ليزان لبنان - ط2

42. المحصول في علم الأصول ـ لفخر الدين الر ازي ، طبعة دار الكتب العلميـة ـ ط1 -

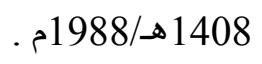

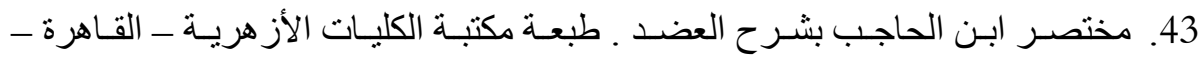

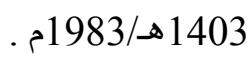

44. المختصر في أصول الفقه ـ لعلاء الدين بن محمد البعلي المعروف بـابن اللحام ، طبعة

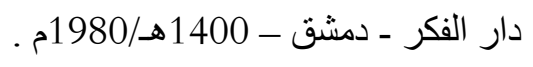

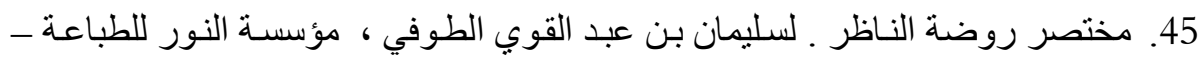

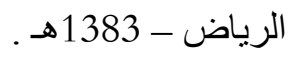

46. المدخل الفقهي العام ، لمصطفى الزرقا ـ دار القلم - دمشق .

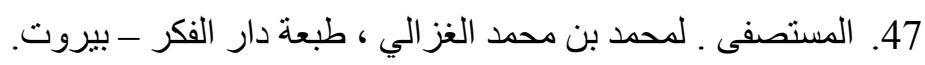

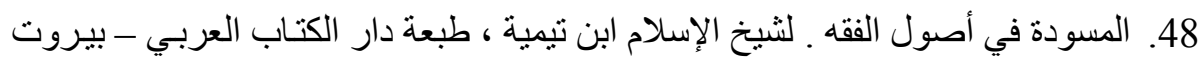

49. المصباح المنير في غريب الثرح الكبير ـ لأحمد الفبومي ، طبعة دار الكتب العلميـة بيروت - لبنان .

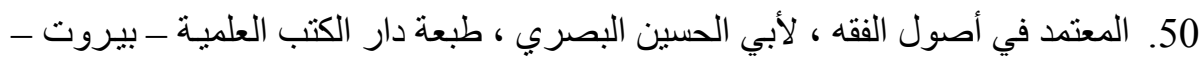

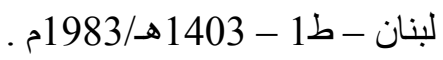

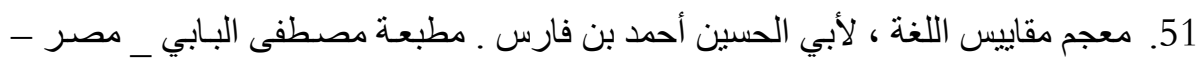

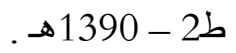




$$
\text { د/ شريفة بنت علي الحوشاني }
$$

52. معجم المؤلفين ـ. لعمر رضا كحالة ، دار إحياء التزاث العربي - بيروت ـ لبنان .

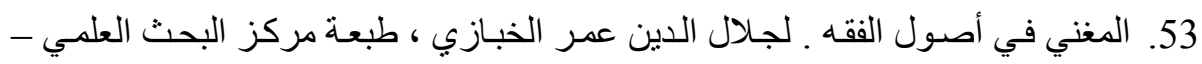

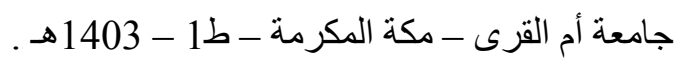

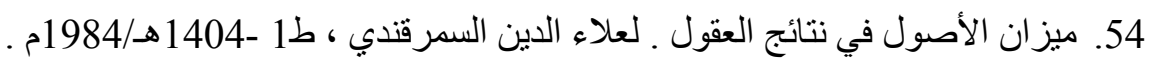

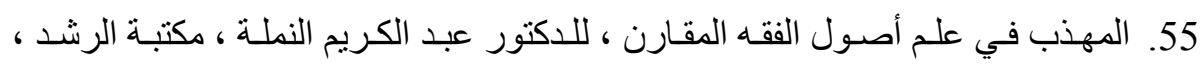

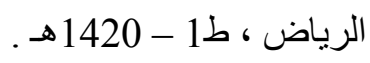

56. المو افقات ـ لأبي إسحاق الثاطبي ، مطبعة مكتبة الرياض الحديثة .

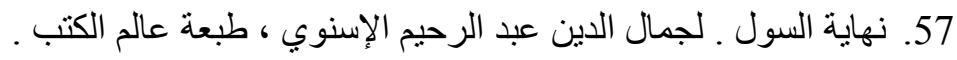

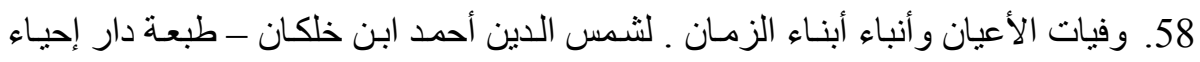

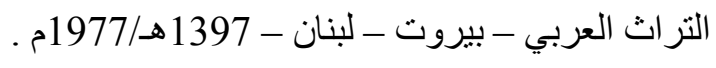

